IZA DP No. 6592

Medical Marijuana Laws and Teen Marijuana Use

D. Mark Anderson

Benjamin Hansen

Daniel I. Rees

May 2012 


\title{
Medical Marijuana Laws and Teen Marijuana Use
}

\author{
D. Mark Anderson \\ Montanta State University \\ Benjamin Hansen \\ University of Oregon \\ Daniel I. Rees \\ University of Colorado Denver \\ and IZA
}

\section{Discussion Paper No. 6592 \\ May 2012}

\author{
IZA \\ P.O. Box 7240 \\ 53072 Bonn \\ Germany
}

Phone: +49-228-3894-0

Fax: +49-228-3894-180

E-mail: iza@iza.org

\begin{abstract}
Any opinions expressed here are those of the author(s) and not those of IZA. Research published in this series may include views on policy, but the institute itself takes no institutional policy positions.

The Institute for the Study of Labor (IZA) in Bonn is a local and virtual international research center and a place of communication between science, politics and business. IZA is an independent nonprofit organization supported by Deutsche Post Foundation. The center is associated with the University of Bonn and offers a stimulating research environment through its international network, workshops and conferences, data service, project support, research visits and doctoral program. IZA engages in (i) original and internationally competitive research in all fields of labor economics, (ii) development of policy concepts, and (iii) dissemination of research results and concepts to the interested public.
\end{abstract}

IZA Discussion Papers often represent preliminary work and are circulated to encourage discussion. Citation of such a paper should account for its provisional character. A revised version may be available directly from the author. 
IZA Discussion Paper No. 6592

May 2012

\section{ABSTRACT}

\section{Medical Marijuana Laws and Teen Marijuana Use}

While at least a dozen state legislatures are considering bills to allow the consumption of marijuana for medicinal purposes, the federal government has recently intensified its efforts to close medical marijuana dispensaries. Federal officials contend that the legalization of medical marijuana encourages teenagers to use marijuana and have targeted dispensaries operating within 1,000 feet of schools, parks and playgrounds. Using data from the national and state Youth Risk Behavior Surveys, the National Longitudinal Survey of Youth 1997 and the Treatment Episode Data Set, we estimate the relationship between medical marijuana laws and marijuana use. Our results are not consistent with the hypothesis that legalization leads to increased use of marijuana by teenagers.

JEL Classification: K4, I1, D8

Keywords: marijuana, youth risky behavior, medical marijuana laws

Corresponding author:

Benjamin Hansen

Department of Economics

1280 University of Oregon

Eugene, OR 97403

USA

E-mail: bchansen@uoregon.edu 
These last couple years, the amount of attention that's been given to medical marijuana has been huge. And when I've done focus groups with high school students in states where medical marijuana is legal, they say "Well, if it's called medicine and it's given to patients by caregivers, then that's really the wrong message for us as high school students.”

--R. Gil Kerlikowske, Director of the Office of National Drug Control Policy

\section{INTRODUCTION}

Tobacco and alcohol use by American high school students has been declining since the mid-1990s. Marijuana use followed a similar trend until the mid-2000s, when, according to data from Monitoring the Future, there was an increase in the percentage of high school students who reported having smoked marijuana in the past 30 days accompanied by a sharp decrease in the percentage of $10^{\text {th }}$ and $12^{\text {th }}$ graders who view regular marijuana use as risky (Johnston et al. 2011). Federal officials, including the Director of the Office of National Drug Control Policy (also known as the "Drug Czar"), have attributed these developments to the legalization of medical marijuana, noting that the medical marijuana industry has grown dramatically since the mid-2000s.

In an effort to combat youth marijuana use, John Walsh, the U.S. Attorney for Colorado, recently sent letters to medical marijuana dispensaries located within 1,000 feet of schools asking them to relocate or close. Walsh cited figures from the Colorado Department of Education showing that drug-related school suspensions, expulsions and law enforcement referrals increased dramatically from 2008 through 2011 (Ingold 2012), and he was quoted as saying that many school districts in Colorado "have seen a dramatic increase in student abuse of marijuana, with resulting student suspensions and discipline” (McCrimmon and Jones 2012). Melinda Haag, the U.S. Attorney for the Northern California district, has targeted dispensaries located within 1,000 feet of schools, parks and playgrounds, arguing that marijuana serves as a gateway 
drug and that, because "brains are not fully developed until your mid 20s”, youth are particularly susceptible to its effects (Brooks 2012). Local law enforcement authorities have also argued that there is a connection between the legalization of medical marijuana and the use of marijuana by teenagers. For instance, Tim O’Connell, the Deputy Police Chief in Billings, Montana, was quoted by Uken (2012) as saying, "We are definitely seeing an increase in the schools, and it’s definitely related to bad legislation...We can thank the passage of legalizing marijuana.”

There is, in fact, evidence that adolescents and young adults who use marijuana are more likely to use other substances such as alcohol and cocaine (Saffer and Chaloupka 1999;

DeSimone and Farrelly 2003; Williams et al. 2004; Yörük and Yörük 2011), as well as evidence that they are more likely to suffer from mental health problems (Fergusson et al. 2003; Van Ours and Williams 2011), partake in risky sexual behaviors (Rashad and Kaestner 2004), and do poorly in school (Yamada et al. 1996; Roebuck et al. 2003; Van Ours and Williams 2009). However, only two previous studies have examined the relationship between medical marijuana laws (hereafter MMLs) and marijuana use among minors. ${ }^{1}$ Drawing on data from the National Survey on Drug Use and Health (NSDUH) for the years 2002 through 2007, Wall et al. (2011) found that rates of marijuana use among 12- through 17-year-olds were higher in states that had legalized medical marijuana than in states that had not, but noted that "in the years prior to MML passage, there was already a higher prevalence of use and lower perceptions of risk” in states that had legalized medical marijuana (p. 714). Drawing on NSDUH data for the years 2002 through

\footnotetext{
${ }^{1}$ Several studies have examined the relationship between MMLs and marijuana consumption without focusing on minors. Khatapoush and Hallfors (2004) used data on 16- though 25-year-olds living in California and 10 other states. They found no evidence that marijuana consumption went up after California legalized medical marijuana in 1996. Using data for the period 1995-2002 from Denver, Los Angeles, Portland, San Diego and San Jose, Gorman and Huber Jr. (2007) found little evidence that marijuana consumption increased among adult arrestees as a result of the legalization of medical marijuana. Cerdá et al. (2012) examined the cross-sectional relationship between MMLs and marijuana use among adults 18 years of age and above.
} 
2009, Harper et al. (2012) found that legalization was associated with a small reduction in the rate of marijuana use among 12- through 17-year-olds.

The current study examines the relationship between MMLs and marijuana consumption among high school students using data from the national and state Youth Risky Behavior Surveys (YRBS) for the years 1993 through 2011. These data cover a period when 16 states, including Alaska, California, Maine, Oregon and Washington, legalized medical marijuana. ${ }^{2}$ The NSDUH did not provide information on substance use at the state level prior to 1999. As a consequence, neither Wall et al. (2011) nor Harper et al. (2012) had information on substance use among 12- through 17-year-olds in these states before legalization occurred.

Another advantage to using the YRBS data is that they contain information on the behavior and characteristics of individuals, allowing us to examine the relationship between MMLs and marijuana use by age and gender. With two exceptions (Khatapoush and Hallfors 2004; Cerdá et al. 2012), previous studies in this area have relied on aggregate data, despite the fact that the choice to smoke marijuana is made at the individual level. Finally, the YRBS data contain information on marijuana use and drug availability at school, and the use of other substances such as alcohol and cocaine. These outcomes are of special interest given the current efforts in California and Colorado to close dispensaries operating near schools and because Melinda Haag, the U.S. Attorney for the Northern California district, has explicitly argued that marijuana is a gateway drug. Our results suggest that the legalization of medical marijuana was not accompanied by increases in the use of marijuana or other substances such as alcohol and

\footnotetext{
${ }^{2}$ Appendix Table 1 provides a list of states that have legalized medical marijuana during the period 1993 through 2011. A number of states legalized medical marijuana prior to 1999, including California, Oregon and Washington. The District of Columbia legalized medical marijuana on July 27, 2010. Although the New Jersey medical marijuana law came into effect on October 1, 2010, implementation has been delayed (Brittain 2012). Coding New Jersey as a non-medical marijuana state in 2011 has no appreciable impact on the results presented below.
} 
cocaine among high school students. Interestingly, several of our estimates suggest that marijuana use actually declined with the passage of MMLs.

In addition to analyzing data from the YRBS, we conduct two complementary analyses. The first uses data from the National Longitudinal Survey of Youth 1997 (NLSY97). The behavior of NLSY97 respondents can be observed over time, allowing for the estimation of models that control for unobserved heterogeneity at the individual level. The second uses data from the Treatment Episode Data Set (TEDS), which contains information from drug treatment providers on patients who reported using marijuana before being admitted. These analyses provide further evidence that youth marijuana consumption did not increase with the legalization of medical marijuana.

\section{BACKGROUND}

In 1996, California became the first state to legalize medical marijuana. Since then, 16 additional states and the District of Columbia have legalized medical marijuana, and more than a dozen state legislatures are currently considering medical marijuana bills (Klofas and Letteney 2012). In addition to removing criminal penalties for using, possessing and cultivating medical marijuana, medical marijuana laws provide immunity from prosecution to physicians who recommend medical marijuana to their patients.

While the therapeutic properties of marijuana are the subject of debate (Gilman 2005; Cohen 2009), the client base of doctors who recommend medical marijuana has expanded to include adolescents with conditions such as autism, insomnia, obsessive compulsive disorder, and attention deficit hyperactivity disorder (Browstein 2009; Ellison 2009; Joseph et al. 2010). ${ }^{3}$

\footnotetext{
${ }^{3}$ Medical marijuana has also been used to treat adolescents suffering from chronic pain. Belkin (2009) described the case of a 9-year-old autistic boy who used medical marijuana to treat constant pain.
} 
Advocates of recommending medical marijuana for these conditions maintain that it is safer than alternative medicines such as methylphenidate (also known as "Ritalin"), the stimulant most often prescribed to treat attention deficit hyperactivity disorder (Lucido 2004; Ellison 2009), and zolpidem tartrate (also known as “Ambien”), a medication prescribed to treat insomnia (Chaboya-Hembree 2012).

Patients under the age of 18 must have the permission of a parent or legal caregiver in order to use medical marijuana, and must be accompanied by a parent or legal caregiver when visiting a dispensary (Ellison 2009). Moreover, there is evidence from registry data that only a small percentage of medical marijuana patients are minors. For instance, only 0.08 percent of medical marijuana patients are under the age of 18 in Arizona; in Montana, 0.13 percent of patients are under the age of $18 .{ }^{4}$ However, because it is prohibitively expensive for the government to ensure that all marijuana ostensibly grown for the medicinal market ends up in the hands of registered patients, diversion to the recreational market almost certainly occurs, and ambiguity surrounding the source of supply creates legitimacy for illegal suppliers and decreases the risk of selling marijuana to recreational users (Pacula et al. 2010). ${ }^{5}$ These supply-side factors could, in theory, lead to lower prices in the illegal market and increase youth consumption.

On the demand side, researchers, policymakers and law enforcement officials contend that legalization reduces the stigma associated with the use of marijuana (Roan 2011; Suthers 2012; Uken 2012) and encourages young people to underestimate the health risks associated with

\footnotetext{
${ }^{4}$ Arizona and Montana are the only MML states that publicly record the age distribution of registered patients.

${ }^{5}$ It has been estimated that thousands of pounds of surplus medical marijuana are diverted to the illegal market in Colorado (Wirfs-Brock et al. 2010). Thurstone et al. (2011) interviewed 80 adolescents (15 through 19 years of age) undergoing outpatient substance abuse treatment in Denver. Thirty-nine of the 80 reported having obtained marijuana from someone with a medical marijuana license. Florio (2011) described the story of four eighth-graders in Montana who received marijuana-laced cookies from a medical marijuana cardholder.
} 
marijuana use (O’Connor 2011; Roan 2011). In addition, legalization could increase demand by providing more opportunities for young people to interact with legitimate users (Pacula et al. 2010). Not surprisingly, past research has shown that attitudes and perceptions with regard to the harmfulness of marijuana are strongly correlated with use (Bachman et al. 1998; Pacula et al. 2001).

Our empirical analysis is reduced-form, based on the approach taken by previous researchers interested in the determinants of marijuana use. For instance, Farrelly et al. (1999) examined the reduced-form relationship between more stringent anti-marijuana policies and marijuana use, while Thies and Register (1993), Saffer and Chaloupka (1999) and Williams (2004) examined the impact of decriminalization. In a similar vein, Pacula (1998), Farrelly et al. (2001), and Williams et al. (2004) examined the impact of alcohol and cigarette policies on marijuana use.

These studies provide some evidence that marijuana use is sensitive to changes in policy. For example, Farrelly et al. (1999) found that stricter enforcement of marijuana laws by police and higher fines for marijuana possession decreased use among adults. However, Farrelly et al. (1999) found that these policies had little impact on marijuana use among those under the age of 21. Using data from the United States, Thies and Register (1993) found that decriminalization did not lead to increased use of marijuana, while Saffer and Chaloupka (1999) found that decriminalization increased the probability of having smoked marijuana in the past 30 days. Using Australian data, Williams (2004) found that decriminalization increased marijuana use among males over the age of 25, but had no effect on marijuana use by females or by younger males. Finally, Farrelly et al. (2001) found that cigarette taxes were negatively related to 
marijuana use, while Williams et al. (2004) found that cigarette prices were essentially unrelated to marijuana use.

\section{THE DATA}

The primary data for this study come from the national and state YRBS. They are at the individual (micro) level and cover the period 1993 through $2011 .^{6}$ The national YRBS is conducted biennially by the Centers for Disease Control and Prevention (CDC) and is a nationally representative sample of U.S. high school students. Federal agencies rely upon the national YRBS to track trends in adolescent behavior including eating and exercise habits, violence, sexuality, and substance use. Previous studies such as Merrill et al. (1999) and AbdelGhany and Wang (2003) have used these data to examine determinants of youth marijuana use. The state surveys are coordinated by the CDC and are administered by state education and health agencies. Like the national YRBS, the state YRBS is school-based and contains multiple items designed to elicit information on risky behaviors. To our knowledge, no previous study has used state YRBS data to examine the determinants of youth marijuana use.

Our analysis draws on both of these data sources in order to ensure that identification is based on as many MML changes as possible. Although intended to be nationally representative, not all 50 states are represented in any given wave of the national YRBS. In fact, between 1993 and 2011, only 6 states contributed data to the national YRBS every year (California, Florida, Georgia, Michigan, New York, and Texas), and 11 states contributed data to the national YRBS before and after the legalization of medical marijuana (Arizona, California, Colorado, Delaware, Hawaii, Maine, Michigan, New Jersey, New Mexico, Oregon, and Washington). Appendix

\footnotetext{
${ }^{6}$ The national YRBS was first conducted in 1991. However, because the 1991 wave is based on only a handful of schools, we chose to omit it from the analysis.
} 
Table 2 shows the number of observations by year and state in the national YRBS. States that legalized medical marijuana are denoted with a star superscript and post-legalization observations are italicized. $^{7}$

With a few exceptions, most states conducted their own version of the YRBS sometime between 1993 and 2011, and at least 15 administered the YRBS in any given year during this period. ${ }^{8}$ However, only 24 states have given the CDC permission to release their data, while 20 states require that requests to use their data be made directly. We have obtained data from 11 of these 20 states, bringing our total to 35, 11 of which conducted surveys before and after the legalization of medical marijuana (Alaska, Arizona, Delaware, Maine, Michigan, Montana, Nevada, New Jersey, New Mexico, Rhode Island, and Vermont). Appendix Table 3 shows the number of observations each state contributed to the state YRBS analysis. Again, states that legalized medical marijuana are denoted with a star superscript and post-legalization observations are italicized.

When combined, the national and state YRBS data cover the District of Columbia and 49 states; sixteen of these states contributed data before and after the legalization of medical marijuana. ${ }^{9}$ Table 1 provides descriptive statistics for the national and state YRBS samples by whether medical marijuana was legal at the time of the interview. According to the national YRBS data, 22 percent of high school students used marijuana at least once in the past 30 days,

\footnotetext{
${ }^{7}$ In the regression analyses, the fraction of the year that the law was in effect was used when a state legalized medical marijuana during a survey year. We experimented with assigning 0 to these years; we also experimented with assigning 1 to these years. The results, which are available upon request, were similar to those reported below.

${ }^{8}$ The following CDC webpage provides a detailed history of the state YRBS: http://www.cdc.gov/healthyyouth/yrbs/history-states.htm.

${ }^{9}$ Wyoming is the only state for which we do not have national YRBS or state YRBS data. Medical marijuana was illegal in Wyoming during the period under study. Although the District of Columbia legalized medical marijuana in 2010, it has never conducted a state YRBS and contributed observations to the national YRBS in only two years, 1995 and 2011.
} 
and 9 percent used marijuana at least 10 times during the past 30 days (our definition of frequent use). In the state YRBS data, 21 percent of respondents used marijuana in the past 30 days and 8 percent were frequent users.

Figure 1 presents trends in marijuana use based on weighted national YRBS data. It shows a steady decline in marijuana use among high school students from the late 1990s through 2007. From 2007 to 2011, the percentage of high school students who used marijuana in the past 30 days increased from 19.7 percent to 23.1 percent. Figure 2 presents trends in marijuana use based on unweighted state YRBS data. Despite the fact that they are designed to be representative at the state level, these data show the same steady decline in marijuana use from the late-1990s through the mid-2000s and a comparable increase after 2007, suggesting that the national and the state YRBS are capturing the same broad changes in tastes and policies.

Figures 3 and 4 present pre- and post-legalization trends in marijuana use based on national and state YRBS data, respectively. We report marijuana use for the three years prior to legalization, the year in which the law changed (year 0), and the three years following legalization. These figures provide simple and direct tests for whether youth marijuana consumption changed with the legalization of medical marijuana. In Figure 3, there appears to be a small decrease in marijuana use immediately after legalization, followed by an increase of comparable magnitude. A similar pattern is evident in Figure 4: marijuana use decreases immediately after legalization, increases after one year, and then decreases again by a comparable amount after two years. Although neither figure provides strong evidence of an increase in marijuana use after legalization, other factors related to, for instance, economic conditions could be masking the impact of legalization. 


\section{STATISTICAL METHODS}

In an effort to control for economic conditions and other policies (as well as any changes in the composition of the YRBS), we turn to a standard regression framework that exploits both temporal and spatial variation in MMLs. Specifically, we estimate the following equation:

$$
\text { Marijuana Use }_{i s t}=\beta_{0}+\beta_{1} M M L_{s t}+\boldsymbol{X} \mathbf{1}_{\text {ist }} \boldsymbol{\beta}_{2}+\boldsymbol{X} \mathbf{2}_{s t} \boldsymbol{\beta}_{3}+v_{s}+w_{t}+\Theta_{s} \cdot t+\varepsilon_{i s t} \text {, }
$$

where $i$ indexes individuals, $s$ indexes states, and $t$ indexes years. The vectors $v_{s}$ and $w_{t}$ represent state and year fixed effects, respectively, and state-specific linear time trends are represented by $\Theta_{s} \cdot t$. The state-specific linear time trends are included to control for unobserved factors at the state level that evolve smoothly over time such as preferences and tastes. The variable $M M L_{s t}$ is an indicator for whether medical marijuana was legal in state $s$ and year $t$. The coefficient of interest, $\beta_{1}$, represents the effect of medical marijuana legislation.

The dependent variable, Marijuana $U_{s e} i_{i s t}$, is equal to 1 if respondent $i$ reported using marijuana in the past 30 days, and equal to 0 otherwise. The vector $\boldsymbol{X} \mathbf{1}_{\text {ist }}$ includes individuallevel controls for age, sex, race and grade, while the vector $\boldsymbol{X} \boldsymbol{2}_{\text {st }}$ includes state-level controls for whether marijuana use and possession was decriminalized, the presence of a BAC 0.08 law, the state beer tax, income per capita, and the unemployment rate. Previous research has shown that marijuana use is sensitive to decriminalization (Saffer and Chaloupka 1999), alcohol policies (Pacula 1998; DiNardo and Lemieux 2001) and economic conditions (Hammer 1992). All regressions are estimated as linear probability models and standard errors are corrected for clustering at the state level (Bertrand et al. 2004). In addition to examining marijuana use in the past 30 days, we examine frequent marijuana use, marijuana use at school, whether the 
respondent was offered or bought marijuana on school property, and the use of other substances including alcohol and cocaine. Descriptive statistics for these outcomes are presented in Table 1.

\section{RESULTS}

Tables 2 through 5 present unweighted OLS estimates of the relationship between MMLs and the outcomes discussed above. Separate estimates for the national and state YRBS are presented along with estimates based on the combined data.

Using the national YRBS and a "bare bones" specification without covariates or statespecific linear time trends, legalization of medical marijuana is associated with a 5.6 percentage point decrease in the probability of marijuana use within the past 30 days, and a 3.5 percentage point decrease in the probability of frequent use (Table 2). We can reject the hypothesis that the relationship between MMLs and these outcomes is positive at conventional levels. The same specification yields smaller, but still negative, estimates of $\beta_{1}$ using the state YRBS data. When the national and state YRBS data are combined, we find that the legalization of medical marijuana is associated with a 2.1 percentage point decrease in the probability of marijuana use within the past 30 days, and a 1.1 percentage point decrease in the probability of frequent use. We can reject the hypothesis that the relationship between legalization and these outcomes is positive at conventional levels.

A similar pattern of results emerges when the covariates and state-specific linear time trends are included on the right-hand side of the estimating equation. In these specifications, the estimates of $\beta_{1}$ are uniformly negative, although they are not statistically distinguishable from 
zero. ${ }^{10}$ Ninety-five percent confidence intervals around the point estimates produced when using the combined YRBS data and controlling for state-specific linear time trends suggest that the impact of legalization on the probability of marijuana use in the past 30 days is no larger than 0.8 percentage points and the impact of legalization on the probability of frequent marijuana use in the past 30 days is no larger than 0.7 percentage points. In comparison, based on nationally representative data from Monitoring the Future, marijuana use among $12^{\text {th }}$ graders increased by 4.3 percentage points from 2006 to 2011; marijuana use among $10^{\text {th }}$ graders increased by 3.4 percentage points over this same period. ${ }^{11}$ Based on national YRBS data, marijuana use among high school students increased by 3.4 percentage points from 2007 to 2011.

In Table 3, we explore whether the relationship between MMLs and marijuana use depends on gender. These estimates are from our preferred specification that includes the full set of covariates and state-specific linear time trends. With one exception, they are negative and statistically indistinguishable from zero. The hypothesis that $\beta_{1}$ for male respondents is equal to $\beta_{1}$ for female respondents is never rejected.

Table 4 compares estimates of $\beta_{1}$ for YRBS respondents who were under the age of 17 when they were interviewed with estimates for respondents who were 17 years of age or older. ${ }^{12}$ In the national YRBS data, the relationship between legalization and marijuana use is negative and significant among respondents under the age of 17, but insignificant among respondents 17

\footnotetext{
${ }^{10}$ Appendix Table 4 presents estimates that incorporate the sample weights provided by the national YRBS. Again, there is little evidence that legalization of medical marijuana led to increased marijuana use among high school students.

${ }^{11}$ Estimates of marijuana use in the past 30 days for $8^{\text {th }}, 10^{\text {th }}$, and $12^{\text {th }}$ graders are available from Johnston et al. (2011) and are based on data from Monitoring the Future. Monitoring the Future has interviewed nationally representative samples of $8^{\text {th }}, 10^{\text {th }}$, and $12^{\text {th }}$ graders since 1991 . However, state identifiers are generally not made available to researchers. Our efforts to obtain these data were politely rebuffed.

12 The YRBS data include information on all high school students, some of whom are as old as 19.
} 
years of age and older. The relationship between legalization and frequent use is negative (but statistically insignificant) among both younger and older respondents. The remaining estimates of $\beta_{1}$ in Table 4 are small and statistically insignificant. ${ }^{13}$

Table 5 reports estimates of the effect of legalization on the use of marijuana on school property in the past 30 days and estimates of the effect of legalization on the probability a student reported having been offered, sold, or given an illegal drug at school in the past year. These estimates are of particular interest given the recent attempts to close dispensaries operating near schools (Brooks 2012; McCrimmon and Jones 2012). The estimated relationship between MMLs and the use of marijuana on school property is consistently negative, but never statistically significant. In the combined sample, legalization is associated with a 2.7 percentage point decrease in the probability of having been offered, sold, or given an illegal drug at school in the past year

Finally, we examine the relationship between the legalization of medical marijuana and the use of other substances in Table 6. Using a regression discontinuity design, Crost and Guerrero (2012) found that marijuana use decreased sharply at the age of 21, suggesting that marijuana and alcohol are substitutes. Other studies suggest that marijuana and substances such as alcohol and cocaine are complements (Saffer and Chaloupka 1999; DeSimone and Farrelly 2003; Williams et al. 2004; Yörük and Yörük 2011). Our results provide little evidence that the legalization of medical marijuana leads to increased use of alcohol or cocaine.

\footnotetext{
${ }^{13}$ Although the results are not reported, we estimated equation (1) for respondents 18 years of age and older. There was no evidence that the legalization of medical marijuana was associated with an increase in marijuana use among this age group. Appendix Table 5 presents estimates that incorporate the sample weights provided by the national YRBS. They are similar to those reported in Table 3 and Table 4.
} 


\subsection{Analysis of the National Longitudinal Survey of Youth 1997}

In this section, we examine the relationship between MMLs and the use of marijuana by youth in the National Longitudinal Survey of Youth 1997 (NLSY97). The NLSY97, which is conducted annually, is a nationally representative sample of individuals who were 12 through 16 years of age as of December $31^{\text {st }}$, 1996. It contains detailed information on educational attainment, family background and socio-economic status, and its respondents are asked a host questions with regard to marijuana use including, "On how many days have you used marijuana in the last 30 days?” ${ }^{14}$ Because our focus is on teenagers, we limit the analysis to respondents ages 12 through 19 at the time of the survey.

There are two primary benefits to using the NLSY97 data. First, unlike the YRBS, the NLSY97 includes high school dropouts. This is important because high school dropouts are more likely to use marijuana than their counterparts who stay in school (Bray et al. 2000). Second, because the NLSY97 data follow adolescents over time, it is possible to control for unobserved heterogeneity at the individual level.

However, there are two significant drawbacks to using NLSY97 data. First, California legalized medical marijuana before data collection began and several other states legalized medical marijuana when most of the NLSY97 respondents were in their twenties and thirties. ${ }^{15}$ Second, several of the states that legalized medical marijuana in the late 1990s and early 2000s contributed only a handful of observations to the NLSY97.

\footnotetext{
${ }^{14}$ Based on the answers to this question, we are able to construct measures of marijuana use that correspond to the marijuana use measures in the YRBS data. Economists who have used these data to study determinants of marijuana use include Aughinbaugh and Gittleman (2004), Cowen (2011), and Yörük and Yörük (2011).

${ }^{15}$ For instance, New Mexico legalized medical marijuana in 2007, when the average age of NLSY97 respondents was 25.
} 
Table 7 presents descriptive statistics from the NLSY97 and Table 8 presents regression results. Specifically, we report estimates from the following equation:

$$
\text { Marijuana Use }_{i s t}=\beta_{0}+\beta_{1} M M L_{s t}+\boldsymbol{X} \mathbf{1}_{\text {ist }} \boldsymbol{\beta}_{2}+\boldsymbol{X} \mathbf{2}_{s t} \boldsymbol{\beta}_{3}+\lambda_{i}+w_{t}+\Theta_{s} \cdot t+\varepsilon_{i s t},
$$

where $i$ indexes individuals, $s$ indexes states, and $t$ indexes years. Year fixed effects are represented by $w_{t}$, and state-specific linear time trends are represented by $\Theta_{s} \cdot t$. The variable $M M L_{s t}$ is defined as above and $\beta_{1}$ represents the effect of medical marijuana legislation on marijuana use in the past 30 days. In addition, we examine the relationship between MMLs and frequent marijuana use defined as having used marijuana on at least 10 of the past 30 days. The vectors $\boldsymbol{X} \mathbf{1}_{\text {ist }}$ and $\boldsymbol{X} \boldsymbol{2}_{\text {st }}$ are composed of the individual- and state-level controls, respectively. ${ }^{16}$ Because NLSY97 respondents are observed in multiple years, we are able to include individual fixed effects, $\lambda_{i}$, on the right-hand side of the estimating equation. In addition to absorbing time-invariant heterogeneity at the individual level, these effects account for factors at the state level that may be correlated with marijuana use and the legalization of medical marijuana, although it is important to note that identification comes from changes in the law and from movement between states with different MMLs. All regressions are estimated as linear probability models and standard errors are corrected for clustering at the state level (Bertrand et al. 2004).

Each cell in Table 8 represents the results from a separate regression. Estimates in column (1) are based on a specification that includes only individual and year fixed effects; estimates in column (2) are based on a specification that also includes the covariates listed in

\footnotetext{
${ }^{16}$ The state-level controls are identical to those used in the YRBS analysis. The individual-levels controls include indicators for education status, which are not available in the YRBS.
} 
Table 7; and estimates in column (3) are based on a specification that adds state-specific linear time trends. Consistent with the YRBS analyses above, there is little evidence to support the hypothesis that MMLs encourage marijuana use by teenagers. Although 5 of the 6 coefficient estimates are positive, none are statistically significant at conventional levels. If the largest estimates are taken at face value, the legalization of medical marijuana is associated with a 0.7 percentage point increase in the probability of marijuana use in the past 30 days, and a 1.3 percentage point increase in the probability of frequent use. Appendix Table 6 presents estimates that incorporate the sample weights provided by the NLSY97. ${ }^{17}$ They are consistent with those reported in Table 8.

\subsection{Analysis of the Treatment Episode Data Set}

Finally, we examine the relationship between MMLs and marijuana use based on statelevel data from the Treatment Episode Data Set (TEDS) for the period 1992 through 2009. Federally funded drug treatment facilities are required to provide information to TEDS including whether a patient reported using marijuana prior to admission. Using these data, we constructed rates of marijuana use at the state level by year. ${ }^{18}$

There are at least two advantages to using the TEDS data. First, like the NLSY97, the TEDS data include high school dropouts. Second, the TEDS data are compiled annually and very few states fail to provide admissions data. In contrast, the YRBS data are collected biennially and only a subset of states contribute data in any given year. Descriptive statistics for the TEDS data are presented in Table 9.

\footnotetext{
${ }^{17}$ Following Mellor (2011), we used the average of the sample weights for each individual for the years in which he or she participated in the NLSY97.

${ }^{18}$ Other economists who have used these data include Anderson (2010), Corman et al. (2010), Cunningham and Finlay (2011), and Nonnemaker et al. (2011).
} 
To estimate the relationship between MMLs and marijuana-positive admission rates, we estimate the following equation:

$$
\ln \left(\text { Marijuana admission rate }{ }_{a s t}\right)=\beta_{0}+\beta_{1} M M L_{s t}+\boldsymbol{X}_{s t} \boldsymbol{\beta}_{2}+v_{s}+w_{t}+\Theta_{s} \cdot t+\varepsilon_{a s t},
$$

where $a$ indexes whether the observed admission rate is for males or females, $s$ indexes states, and $t$ indexes years. The dependent variable is the natural logarithm of the sex-specific marijuana admissions rate per 100,000 of the relevant population. Because TEDS does not provide the exact age or date of birth, we consider marijuana admission rates for two age groups: 15- through 17-year-olds and 18- through 20-year-olds. Again, the variable $M M L_{s t}$ indicates whether a MML was in effect in state $s$ and year $t$, the vector $\boldsymbol{X}_{\boldsymbol{s t}}$ is composed of the controls described in Table 9, and $v_{s}$ and $w_{t}$ are state and year fixed effects, respectively, and state-specific linear time trends are represented by $\Theta_{s} \cdot t$.

Table 10 presents the estimates from (3). ${ }^{19}$ Each cell represents the results of a separate regression. Estimates in column (1) are based on specifications that only include state and year fixed effects. The estimates in column (2) are based on specifications that add the covariates, and the estimates in column (3) are based on specifications that include state-specific linear time trends. Consistent with the YRBS and NLSY97 analyses above, there is no evidence to support the hypothesis that MMLs increase marijuana use among 15- through 17-year-olds. In fact, the estimates of $\beta_{1}$, although statistically insignificant, are uniformly negative. Likewise, there is no evidence that medical marijuana laws are associated with increased use among 18- through 20year-olds.

\footnotetext{
${ }^{19}$ The slight difference in sample size between estimates for 15- through 17-year-olds and 18- through 20-year-olds is due to missing values.
} 


\section{CONCLUSION}

Medical marijuana is popular with the general public. A recent Gallup poll found that 70 percent of Americans say they favor making marijuana legally available for doctors to prescribe in order to reduce pain and suffering (Mendes 2010).

Given this level of support, it could be viewed as surprising that only 17 states have legalized medical marijuana. However, opponents of medical marijuana have employed a number of effective arguments, several of which focus on the use of marijuana by teenagers. For instance, Montana State Senator Jeff Essmann was quoted in 2011 as saying, "The number one goal is to reduce access and availability to the young people of this state that are being sent an incorrect message that this is an acceptable product for them to be using” (Florio 2011).

In order to examine the relationship between medical marijuana laws and youth consumption, we draw on data from the national and state Youth Risk Behavior Surveys (YRBS) for the years 1993 through 2011. These data cover a period when 16 states, including California, Colorado, Montana, Oregon and Washington, legalized medical marijuana, and allow us to estimate the effect of legalization on outcomes such as marijuana use in the past month, frequent marijuana use, and the use of other substances such as alcohol and cocaine.

Our results are not consistent with the hypothesis that the legalization of medical marijuana caused an increase in the use of marijuana and other substances among high school students. In fact, estimates from our preferred specifications are consistently negative and are never statistically distinguishable from zero. Using the 95 percent confidence interval around these estimates suggests that the impact of legalizing medical marijuana on the probability of marijuana use in the past 30 days is no larger than 0.8 percentage points, and the impact of 
legalization on the probability of frequent marijuana use in the past 30 days is no larger than 0.7 percentage points. In comparison, based on nationally representative data from Monitoring the Future, marijuana use in the past 30 days among 12th graders increased by 4.3 percentage points from 2006 to 2011 (Johnston et al. 2011); based on national YRBS data, marijuana use among high school students increased by 3.4 percentage points from 2007 to 2001.

In addition to the YRBS analysis, we examine data from the National Longitudinal Survey of Youth 1997 (NLSY97) and the Treatment Episode Data Set (TEDS). The NLSY97 allows us to follow survey respondents over time, while the TEDS data allow us to examine a high-risk population. There is little evidence that marijuana use is related to the legalization of medical marijuana in either of these data sources, a result that is consistent with research showing that marijuana use among adults is more sensitive to changes in policy than marijuana use among youths (Farrelly et al. 1999; Williams 2004).

Although our estimates do not lend support to the often-voiced argument that legalization leads to increased consumption of marijuana among teenagers, it is important to note that our study has at least one limitation: the YRBS data are only available through 2011 and the TEDS data are only available through 2009. In the past year, several states have seen dramatic changes to the market for medical marijuana. For instance, as a result of Drug Enforcement Agency raids, the number of providers in Montana has plummeted. As future waves of the YRBS are released, researchers will be in a position to update our estimates and explore whether these changes have affected the behavior of teenagers. 


\section{REFERENCES}

Abdel-Ghany, Mohamed and Min Qi Wang. "Contemporaneous and Intertemporal Relationship Between the Consumption of Licit and Illicit Substances by Youth.” Journal of Family and Economic Issues 24: 281-289.

Anderson, D. Mark. 2010. "Does Information Matter? The Effect of the Meth Project on Meth Use among Youths.” Journal of Health Economics 29: 732-742.

Anderson, D. Mark, Daniel I. Rees and Benjamin Hansen. 2011. "Medical Marijuana Laws, Traffic Fatalities, and Alcohol Consumption.” IZA Working Paper No. 6112.

Aughinbaugh, Alison and Maury Gittleman. 2004. "Maternal Employment and Adolescent Risky Behavior.” Journal of Health Economics 23: 815-838.

Bachman, Jerald, Lloyd Johnston and Patrick O’Malley. 1998. “Explaining Recent Increases in Students’ Marijuana Use: Impacts of Perceived Risks and Disapproval, 1976 through 1996.” American Journal of Public Health 88: 887-892.

Bray, Jeremy, Gary Zarkin, Chris Ringwalt and Junfeng Qi. 2000. “The Relationship between Marijuana Initiation and Dropping Out of High School.” Health Economics 9: 9-18.

Belkin, Lisa. 2009. “Medical Marijuana for Children.” New York Times. Available at: http://parenting.blogs.nytimes.com/2009/10/20/medical-marijuana-for-children/.

Bertrand, Marianne, Esther Duflo and Sendhil Mullainathan. 2004. "How Much Should We Trust Differences-in-Differences Estimates?” Quarterly Journal of Economics 119: 249276.

Brittain, Amy. 2012. "Medical Marijuana Boss: Gov. Christie's Pot Program Delay is Sabotage.” The Star Ledger, March 23. Available at: http://www.nj.com/news/index.ssf/2012/03/medicial_marijuana_boss_gov_ch.html.

Brooks, Jon. 2012. “Interview with U.S. Attorney Haag on Pot Operations: 'If it's close to children, that's a line we're going to draw."” KQED News. Available at: http://blogs.kqed.org/newsfix/2012/03/15/interview-w-us-attorney-haag-on-potoperations-if-its-close-to-children-thats-a-line-were-going-to-draw/.

Brownstein, Joseph. 2009. “Mother Gives Son Marijuana to Treat His Autism.” ABC News. Available at: http://abcnews.go.com/GMA/AutismNews/mother-son-marijuana-treatautism/story?id=9153881\#.T3pC69WrH0U.

Centers for Disease Control and Prevention. 2004. "Methodology of the Youth Risk Behavior Surveillance System.” Morbidity and Mortality Weekly Report 53: 1-14. 
Cerdá, Magdalenda, Melanie Wall, Katherine Keyes, Sandro Galea and Deborah Hasin. 2012. "Medical Marijuana Laws in 50 States: Investigating the Relationship between State Legalization of Medical Marijuana and Marijuana Use, Abuse and Dependence.” Drug and Alcohol Dependence 120: 22-27.

Chaboya-Hembree, Jan. 2012. “Medical Marijuana and Insomnia.” Available at: http://medicalmarijuana.com/medical-uses/condition.cfm?conID=44.

Chaloupka, Frank and Adit Laixuthai. 1997. "Do Youths Substitute Alcohol and Marijuana? Some Econometric Evidence.” Eastern Economic Journal 23: 253-275.

Cohen, Peter. 2009. "Medical Marijuana: The Conflict Between Scientific Evidence and Political Ideology.” Utah Law Review 1: 35-104.

Corman, Hope, Dhaval Dave, Nancy Reichman and Dhiman Das. 2010. "Effects of Welfare Reform on Illicit Drug Use of Adult Women.” NBER Working Paper No. 16072.

Cowen, Benjamin. 2011. "Forward-thinking Teens: The Effects of College Costs on Adolescent Risky Behavior.” Economics of Education Review 30: 813-825.

Crost, Benjamin and Santiago Guerrero. 2012. "The Effect of Alcohol Availability on Marijuana Use: Evidence from the Minimum Legal Drinking Age.” Journal of Health Economics 31: 112-121.

Cunningham, Scott and Keith Finlay. 2011. "Parental Substance Abuse and Foster Care: Evidence from Two Methamphetamine Supply Shocks?” Working Paper, Baylor University.

DeSimone, Jeff and Matthew Farrelly. 2003. "Price and Enforcement Effects on Cocaine and Marijuana Demand.” Economic Inquiry 41: 98-115.

DiNardo, John and Thomas Lemieux. 2001. “Alcohol, Marijuana, and American Youth: The Unintended Consequences of Government Regulation.” Journal of Health Economics 20: 991-1010.

Ellison, Katherine. 2009. “Medical Marijuana: No Longer Just for Adults.” New York Times. Available at: http://www.nytimes.com/2009/11/22/health/22sfmedical.html.

Farrelly, Matthew, Jeremy Bray, Gary Zarkin, Brett Wendling and Rosalie Pacula. 1999. “The Effects of Prices and Policies on the Demand for Marijuana: Evidence from the National Household Surveys on Drug Abuse.” NBER Working Paper No. 6940.

Farrelly, Matthew, Jeremy Bray, Gary Zarkin and Brett Wendling. 2001. “The Joint Demand for Cigarettes and Marijuana: Evidence from the National Household Surveys on Drug Abuse.” Journal of Health Economics 20: 51-68. 
Fergusson, D.M., L.J. Horwood and N.R. Swain-Campbell. 2003. “Cannabis Dependence and Psychotic Symptoms in Young People.” Psychological Medicine 33: 15-21.

Florio, Gwen. 2011. “Kids’ Use of Medical Marijuana Stirs Debate Over Future in Montana.” Missoulian. Available at: http://missoulian.com/news/local/article_fe14a69c-5833-11e0-9593-001cc4c002e0.html.

Gilman, Victoria. 2005. “The Marijuana Debate: Healing Herb or Dangerous Drug?” National Geographic News. Available at: http://news.nationalgeographic.com/news/2005/06/0621_050621_marijuana.html.

Gorman, Dennis M. and J. Charles Huber Jr. 2007. “Do Medical Cannabis Laws Encourage Medical Cannabis Use? International Journal of Drug Policy 18: 160-167.

Hammer, Torlid. 1992. "Unemployment and Use of Drug and Alcohol among Young People: A Longitudinal Study in the General Population.” British Journal of Addiction 87: 15711581.

Harper, Sam, Erin Strumpf and Jay Kaufman. 2012. "Do Medical Marijuana Laws Increase Marijuana Use? Replication Study and Extension.” Annals of Epidemiology 22: 207-212.

Ingold, John. 2012. “U.S. Attorney John Walsh Justifies Federal Crackdown on MedicalMarijuana Shops.” Denver Post. Available at: http://www.denverpost.com/news/marijuana/ci_19780414.

Joseph, Jennifer and Astrid Rodrigues. 2010. “Marijuana From Mom: Mother Says Drug Helps Son Cope with Severe OCD.” ABC News. Available at: http://abcnews.go.com/2020/MindMoodNews/marijuana-alternative-treatment-childrenocd-autism/story?id=11227283\#.T3pCiNWrH0V.

Johnston, Lloyd, Patrick O’Malley, Jerald Bachman and John Schulenberg. 2011. "Monitoring the Future: National Results on Adolescent Drug Use. Overview of Key Findings, 2011.” Institute for Social Research, University of Michigan. Available at: http://www.monitoringthefuture.org/pubs/monographs/mtf-overview2011.pdf.

Khatapoush, Shereen and Denise Hallfors. 2004. “'Sending the Wrong Message’: Did Medical Marijuana Legalization in California Change Attitudes about and Use of Marijuana?” Journal of Drug Issues 34: 751-770.

Klofas, John and Kyle Letteney. 2012. “The Social and Legal Effects of Medical Marijuana: State Legislation and Rules.” Working Paper, Center for Public Safety Initiatives, Rochester Institute of Technology.

Lucido, Frank. 2004. "Implementation of the Compassionate use Act in a Family Medicine Practice: Seven Years Clinical Experience.” Available at: 
http://www.medboardwatch.com.

McCrimmon, Katie and Rebecca Jones. 2012. "Feds Warn Marijuana Shops Close to Schools.” Education News Colorado. Available at:

http://www.ednewscolorado.org/2012/01/13/31121-feds-warn-medical-marijuanafacilities-near-schools.

Merrill, Jeffrey, Herbert Kleber, Michael Shwartz, Hong Liu and Susan Lewis. 1999.

"Cigarettes, Alcohol, Marijuana, Other Risk Behaviors, and American Youth.” Drug and Alcohol Dependence 56: 205-212.

Nonnemaker, James, Mark Engelen and Daniel Shive. 2011. “Are Methamphetamine Precursor Control Laws Effective Tools to Fight the Methamphetamine Epidemic?” Health Economics 20: 519-531.

O’Connor, Anahad. 2011. “Marijuana Use Growing Among Teenagers.” New York Times. Available at: http://well.blogs.nytimes.com/2011/12/14/marijuana-growing-in-popularity-amongteenagers/.

Pacula, Rosalie. 1998. “Does Increasing the Beer Tax Reduce Marijuana Consumption?” Journal of Health Economics 17: 557-585.

Pacula, Rosalie, Michael Grossman, Frank Chaloupka, Patrick O’Malley, Lloyd Johnston and Matthew Farrelly. 2001. "Marijuana and Youth.” In Jonathan Gruber, ed., Risky Behavior among Youths: An Economic Analysis. Chicago, IL: University of Chicago Press.

Rashad, Inas and Robert Kaestner. 2004. "Teenage Sex, Drugs and Alcohol: Problems Identifying the Cause of Risky Behaviors.” Journal of Health Economics 23: 493-503.

Roan, Shari. 2011. “Medical Marijuana Laws Linked to Higher Overall Usage.” Los Angeles Times. Available at:

http://articles.latimes.com/2011/sep/01/news/la-heb-medical-marijuana-20110901.

Saffer, Henry and Frank Chaloupka. 1999. “The Demand for Illicit Drugs.” Economic Inquiry 37: 401-411.

Suthers, John. 2012. “Medical Marijuana a Threat to Colorado’s Children.” Solutions. Available at: http://www.healthpolicysolutions.org/2012/02/04/opinion-medical-marijuana-a-threat-tocolorados-children/.

Thies, Clifford and Charles Register. 1993. "Decriminalization of Marijuana and the Demand for Alcohol, Marijuana and Cocaine.” Social Science Journal 30: 385-399. 
Thurstone, Christian, Shane Lieberman and Sarah Schmiege. 2011. "Medical Marijuana Diversion and Associated Problems in Adolescent Substance Treatment.” Drug and Alcohol Dependence 118: 489-492.

Uken, Cindy. 2012. “Too Much Pot.” Billings Gazette 6 April 2002: A1.

Van Ours, Jan and Jenny Williams. 2009. "Why Parents Worry: Initiation into Cannabis Use by Youth and their Educational Attainment.” Journal of Health Economics 28: 132-142.

Van Ours, Jan and Jenny Williams. 2011. "Cannabis Use and Mental Health Problems.” Journal of Applied Econometrics 26: 1137-1156.

Wall, Melanie M., Ernest Poh, Magdalenda Cerdá, Katherine M. Keyes, Sandro Galea and Deborah S. Hasin. 2011. “Adolescent Marijuana Use from 2002 to 2008: Higher in States with Medical Marijuana Laws, Cause Still Unclear.” Annals of Epidemiology 21: 714716.

Williams, Jenny. 2004. "The Effects of Price and Policy on Marijuana Use: What Can Be Learned from the Australian Experience?” Health Economics 13: 123-137.

Williams, Jenny, Rosalie Pacula, Frank Chaloupka and Henry Wechsler. 2004. “Alcohol and Marijuana Use among College Students: Economic Complements or Substitutes?” Health Economics 13: 825-843.

Yamada, Tetsuji, Michael Kendix and Tadashi Yamada. 1996. “The Impact of Alcohol Consumption and Marijuana Use on High School Graduation.” Health Economics. 5: 7792.

Yörük, Bariş and Ceren Yörük. 2011. "The Impact of Minimum Legal Drinking Age Laws on Alcohol Consumption and Marijuana Use: Evidence from a Regression Discontinuity Design Using Exact Date of Birth.” Journal of Health Economics 30: 740-753. 


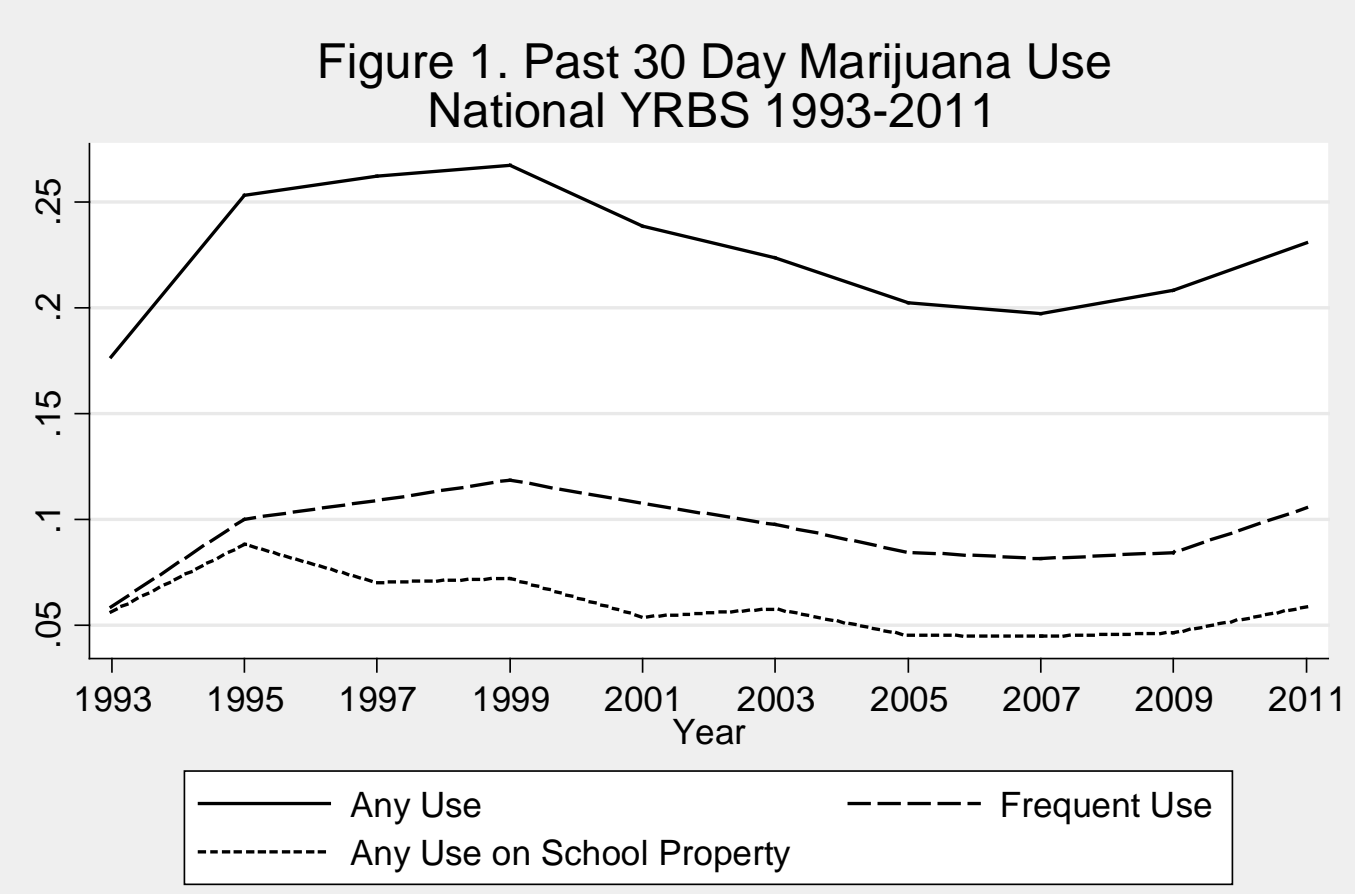

Based on weighted data from the national YRBS. Appendix Table 1 presents information on which states passed a MML between 1993 and 2011.

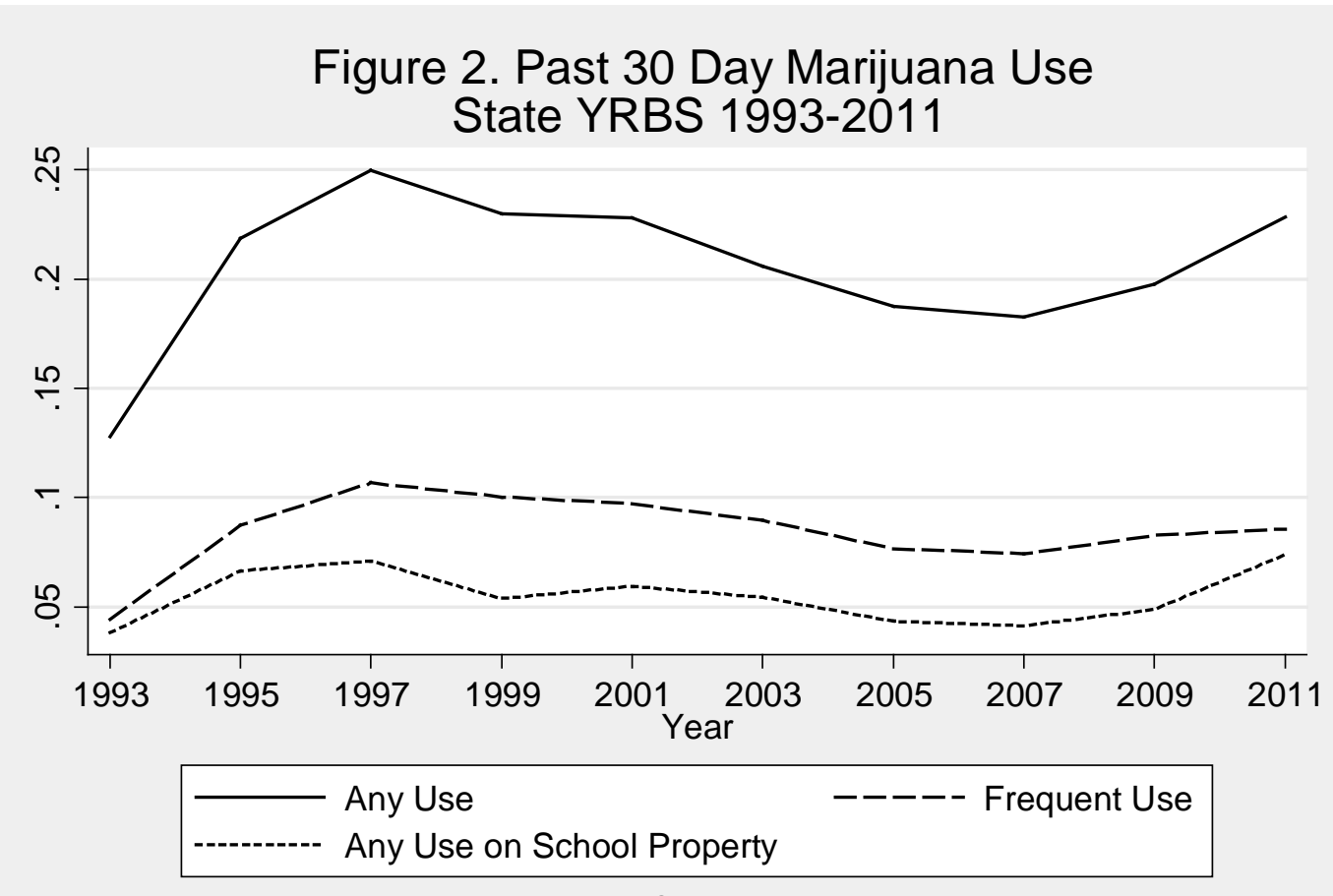

Based on unweighted data from the state YRBS. Appendix Table 1 presents information on which states passed a MML between 1993 and 2011. 


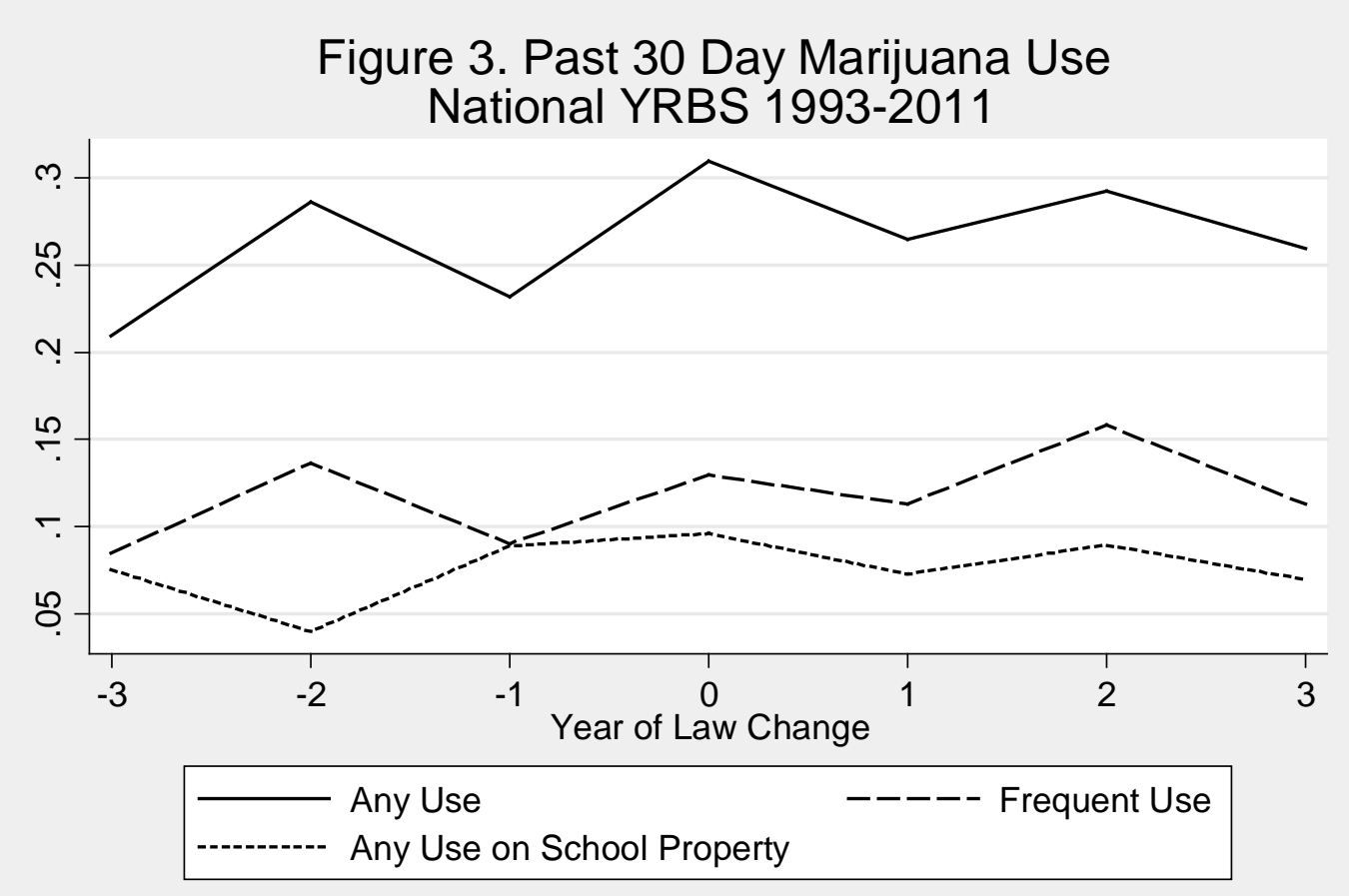

Based on weighted data from the national YRBS. Appendix Table 1 presents information on which states passed a MML between 1993 and 2011.

Figure 4. Past 30 Day Marijuana Use State YRBS 1993-2011

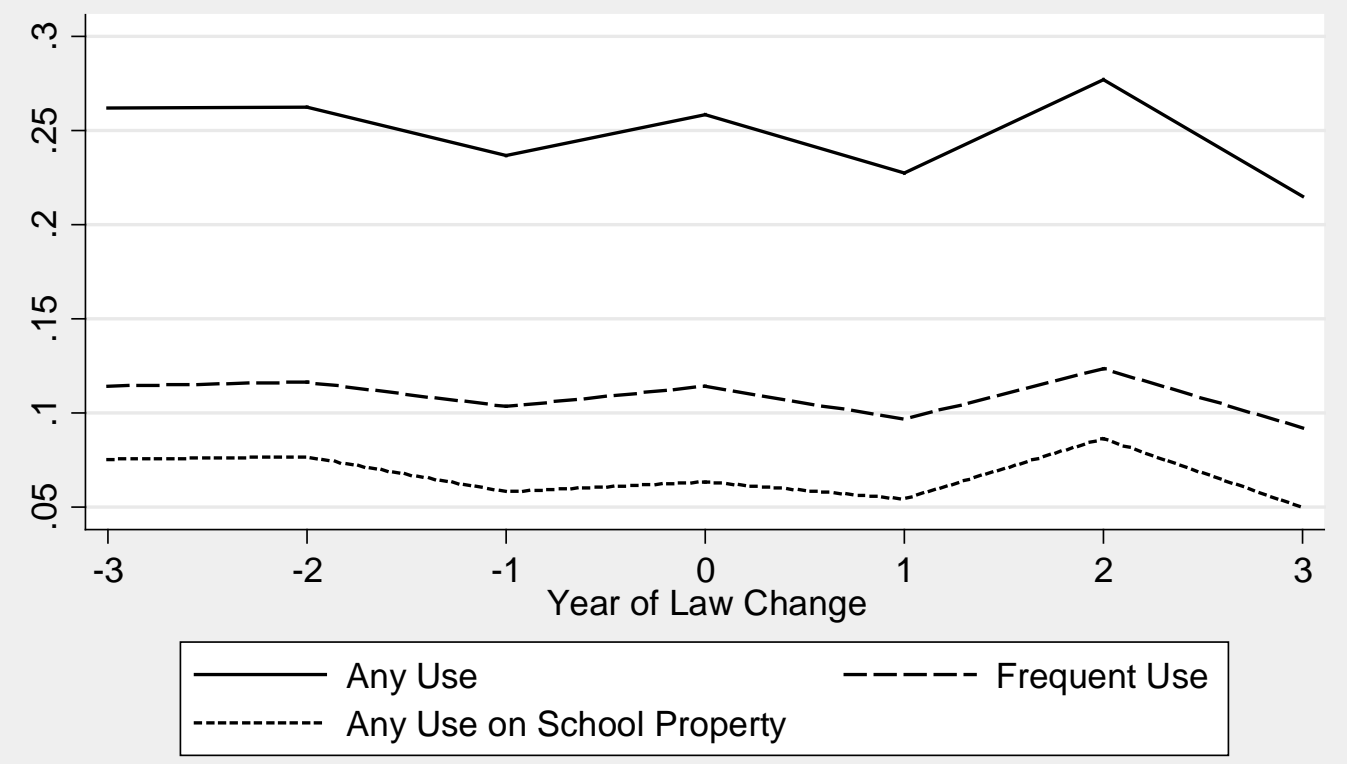

Based on unweighted data from the state YRBS. Appendix Table 1 presents information on which states passed a MML between 1993 and 2011. 
Table 1. Descriptive Statistics: YRBS 1993-2011

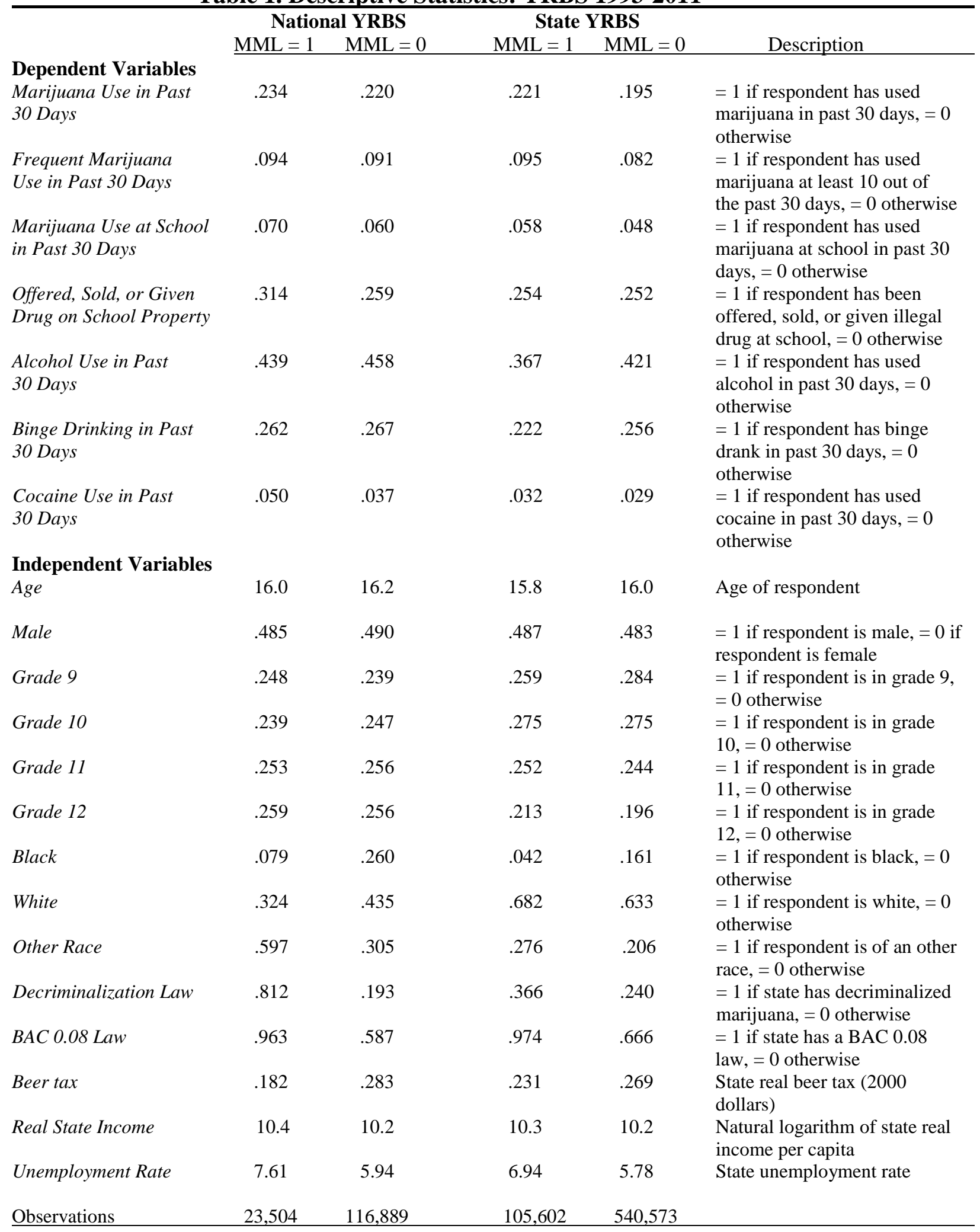

Notes: Means are based on unweighted data from the national and state YRBS (1993-2011). 
Table 2. Medical Marijuana Laws and Youth Consumption, 1993-2011

\section{National YRBS}

Panel A: Marijuana Use in Past 30 Days

MML

$$
\begin{array}{rcc}
-.056 * * * & -.047^{* * *} & -.029 \\
(0.019) & (.014) & (.026)
\end{array}
$$

Observations $\underline{\text { State YRBS }}$

$\begin{array}{ccl}-.014 * & -.011 & -.005 \\ (.008) & (.010) & (.006) \\ & & \\ 646,175 & 646,175 & 646,175\end{array}$

Combined National and State

$$
\begin{array}{ccc}
-.021 * * & -.019 * & -.010 \\
(.009) & (.010) & (.009) \\
& & \\
786,568 & 786,568 & 786,568
\end{array}
$$

Panel B: Frequent Marijuana Use in Past 30 Days

\begin{tabular}{lccccccccc} 
MML & $-.035^{* *}$ & $-.030^{* * *}$ & -.016 & -.006 & -.004 & -.003 & $-.011^{*}$ & -.009 & -.007 \\
& $(.015)$ & $(.011)$ & $(.018)$ & $(.005)$ & $(.005)$ & $(.004)$ & $(.006)$ & $(.006)$ & $(.007)$ \\
Observations & & & & & & & & & \\
State FEs & 140,393 & 140,393 & 140,393 & 646,175 & 646,175 & 646,175 & 786,568 & 786,568 & 786,568 \\
Year FEs & Yes & Yes & Yes & Yes & Yes & Yes & Yes & Yes & Yes \\
Covariates & Yes & Yes & Yes & Yes & Yes & Yes & Yes & Yes & Yes \\
State-specific trends & No & Yes & Yes & No & Yes & Yes & No & Yes & Yes \\
\hline
\end{tabular}

* Statistically significant at $10 \%$ level; ** at $5 \%$ level; *** at $1 \%$ level.

Notes: Each cell represents a separate OLS estimate based on data from the YRBS (1993-2011); the covariates are listed in Table 1. Standard errors, corrected for clustering at the state level, are in parentheses. 
Table 3. Medical Marijuana Laws and Youth Consumption by Gender

\begin{tabular}{|c|c|c|c|c|c|c|}
\hline & \multicolumn{2}{|c|}{$\underline{\text { National YRBS }}$} & \multicolumn{2}{|c|}{$\underline{\text { State YRBS }}$} & \multicolumn{2}{|c|}{$\underline{\text { Combined National and State }}$} \\
\hline \multicolumn{7}{|c|}{ Panel A: Marijuana Use in Past 30 Days } \\
\hline & Male & Female & Male & Female & Male & Female \\
\hline MML & $\begin{array}{l}.029 \\
(.026)\end{array}$ & $\begin{array}{l}-.028 \\
(.028)\end{array}$ & $\begin{array}{l}.002 \\
(.009)\end{array}$ & $\begin{array}{c}-.009 \\
(.009)\end{array}$ & $\begin{array}{l}-.006 \\
(.013)\end{array}$ & $\begin{array}{c}-.012 \\
(.013)\end{array}$ \\
\hline Observations & 68,675 & 71,718 & 312,728 & 333,447 & 381,403 & 406,205 \\
\hline \multicolumn{7}{|c|}{ Panel B: Frequent Marijuana Use in Past 30 Days } \\
\hline & Male & Female & Male & Female & Male & Female \\
\hline MML & $\begin{array}{l}. .014 \\
(.020)\end{array}$ & $\begin{array}{l}-.017 \\
(.016)\end{array}$ & $\begin{array}{l}.002 \\
(.005)\end{array}$ & $\begin{array}{l}-.004 \\
(.004)\end{array}$ & $\begin{array}{l}-.005 \\
(.008)\end{array}$ & $\begin{array}{l}-.007 \\
(.006)\end{array}$ \\
\hline Observations & 68,675 & 71,718 & 254,371 & 333,447 & 381,403 & 406,205 \\
\hline State FEs & Yes & Yes & Yes & Yes & Yes & Yes \\
\hline Year FEs & Yes & Yes & Yes & Yes & Yes & Yes \\
\hline Covariates & Yes & Yes & Yes & Yes & Yes & Yes \\
\hline State-specific trends & Yes & Yes & Yes & Yes & Yes & Yes \\
\hline
\end{tabular}

* Statistically significant at $10 \%$ level; ** at $5 \%$ level; *** at $1 \%$ level.

Notes: Each cell represents a separate OLS estimate based on data from the YRBS (1993-2011); the covariates are listed in Table 1. Standard errors, corrected for clustering at the state level, are in parentheses. 


\section{Table 4. Medical Marijuana Laws and Youth Consumption by Age Group}

National YRBS

$\underline{\text { State YRBS }}$

Combined National and State

Panel A: Marijuana Use in Past 30 Days

MML

\begin{tabular}{cccccc} 
Age $<17$ & Age $\geq 17$ & Age $<17$ & Age $\geq 17$ & Age $<17$ & Age $\geq 17$ \\
\hline$-.046^{*}$ & -.006 & -.008 & .002 & -.012 & -.006 \\
$(.023)$ & $(.035)$ & $(.007)$ & $(.010)$ & $(.011)$ & $(.018)$
\end{tabular}

Observations

$80,494 \quad 59,899$

423,043 222,132

492,457

282,031

Panel B: Frequent Marijuana Use in Past 30 Days

MML

\begin{tabular}{cc} 
Age $<17$ & Age \\
\hline-.018 & $(.017)$
\end{tabular}

Observations

State FEs

Year FEs

Covariates

State-specific trends

$\begin{array}{cc}\text { 80,494 } & 59,899 \\ \text { Yes } & \text { Yes } \\ \text { Yes } & \text { Yes } \\ \text { Yes } & \text { Yes } \\ \text { Yes } & \text { Yes }\end{array}$

$\begin{array}{ccc}\text { Age } \geq 17 & \text { Age }<17 & \text { Age } \geq 17 \\ -.014 & -.002 & -.005 \\ (.021) & (.003) & (.006) \\ & & \\ 59,899 & 423,043 & 222,132 \\ \text { Yes } & \text { Yes } & \text { Yes } \\ \text { Yes } & \text { Yes } & \text { Yes } \\ \text { Yes } & \text { Yes } & \text { Yes } \\ \text { Yes } & \text { Yes } & \text { Yes }\end{array}$

$\begin{array}{cc}\text { Age }<17 & \text { Age } \geq 17 \\ -.005 & -.008 \\ (.006) & (.009)\end{array}$

* Statistically significant at $10 \%$ level; ** at $5 \%$ level; *** at $1 \%$ level.

Notes: Each cell represents a separate OLS estimate based on data from the YRBS (1993-2011); the covariates are listed in Table 1. Standard errors, corrected for clustering at the state level, are in parentheses. 


\section{$\underline{\text { National YRBS }} \underline{\text { State YRBS }}$ Combined National and State}

Panel A: Marijuana Use at School in Past 30 Days

MML

Observations
$-.013$

(.018)

140,393
$-.002$

$(.003)$

577,229
$-.004$

$(.007)$

717,622

Panel B: Offered, Sold, or Given Drug in Past 12 Months on School Property

\begin{tabular}{lccc} 
MML & -.023 & $-.031^{* *}$ & $-.027^{* *}$ \\
Observations & $(.018)$ & $(.014)$ & $(.013)$ \\
& 140,393 & 612,488 & 752,881 \\
State FEs & & & \\
Year FEs & Yes & Yes & Yes \\
Covariates & Yes & Yes & Yes \\
State Linear Trends & Yes & Yes & Yes \\
\hline
\end{tabular}

* Statistically significant at 10\% level; ** at 5\% level; *** at $1 \%$ level.

Notes: Each cell represents a separate OLS estimate based on data from the YRBS (1993-2011); the covariates are listed in Table 1. Standard errors, corrected for clustering at the state level, are in parentheses. The sample sizes in Panel B are smaller than those in Panel A because several states did not ask the Offered, Sold, or Given Drug in Past 12 Months on School Property question every year. 
Table 6. Medical Marijuana Laws and Other Substances

\begin{tabular}{|c|c|c|c|}
\hline & National YRBS & State YRBS & $\underline{\text { Combined National and State }}$ \\
\hline \multicolumn{4}{|c|}{ Panel A: Alcohol Use in Past 30 days } \\
\hline MML & $\begin{array}{c}.016 \\
(.028)\end{array}$ & $\begin{array}{l}-.011 \\
(.009)\end{array}$ & $\begin{array}{l}-.006 \\
(.009)\end{array}$ \\
\hline Observations & 135,537 & 612,004 & 747,541 \\
\hline \multicolumn{4}{|c|}{ Panel B: Binge Drinking in Past 30 Days } \\
\hline MML & $\begin{array}{c}.001 \\
(.019)\end{array}$ & $\begin{array}{l}-.009 \\
(.008)\end{array}$ & $\begin{array}{l}-.005 \\
(.008)\end{array}$ \\
\hline Observations & 141,690 & 625,625 & 768,315 \\
\hline \multicolumn{4}{|c|}{ Panel C: Cocaine Use in Past 30 Days } \\
\hline MML & $\begin{array}{l}-.012 \\
(.011)\end{array}$ & $\begin{array}{l}-.004^{*} \\
(.003)\end{array}$ & $\begin{array}{l}-.009 * \\
(.005)\end{array}$ \\
\hline Observations & 141,626 & 542,724 & 684,350 \\
\hline State FEs & Yes & Yes & Yes \\
\hline Year FEs & Yes & Yes & Yes \\
\hline Covariates & Yes & Yes & Yes \\
\hline State Linear Trends & Yes & Yes & Yes \\
\hline
\end{tabular}

* Statistically significant at $10 \%$ level; ** at 5\% level; *** at $1 \%$ level.

Notes: Each cell represents a separate OLS estimate based on data from the YRBS (1993-2011); the covariates are listed in Table 1. Standard errors, corrected for clustering at the state level, are in parentheses. 
Table 7. Descriptive Statistics: NLSY97

\begin{tabular}{|c|c|c|c|}
\hline \multicolumn{4}{|l|}{ Dependent Variables } \\
\hline $\begin{array}{l}\text { Marijuana Use in Past } \\
30 \text { Days }\end{array}$ & .161 & .145 & $\begin{array}{l}=1 \text { if respondent has used marijuana } \\
\text { in past } 30 \text { days, }=0 \text { otherwise }\end{array}$ \\
\hline $\begin{array}{l}\text { Frequent Marijuana Use } \\
\text { in Past } 30 \text { Days }\end{array}$ & .061 & .058 & $\begin{array}{l}=1 \text { if respondent has used marijuana } \\
\text { at least } 10 \text { out of the past } 30 \text { days, } \\
=0 \text { otherwise }\end{array}$ \\
\hline \multicolumn{4}{|l|}{ Independent Variables } \\
\hline Age & 16.8 & 16.6 & Age of respondent \\
\hline No High School Degree & .728 & .771 & $\begin{array}{l}=1 \text { if respondent has no high school } \\
\text { degree, }=0 \text { otherwise }\end{array}$ \\
\hline GED/High School Degree & .271 & .228 & $\begin{array}{l}=1 \text { if respondent has a GED or a } \\
\text { high school degree, }=0 \text { otherwise }\end{array}$ \\
\hline Over High School Degree & .001 & .000 & $\begin{array}{l}=1 \text { if respondent has more than a } \\
\text { high school degree, }=0 \text { otherwise }\end{array}$ \\
\hline Decriminalization Law & .909 & .225 & $\begin{array}{l}=1 \text { if state has decriminalized } \\
\text { marijuana, }=0 \text { otherwise }\end{array}$ \\
\hline BAC 0.08 Law & .920 & .326 & $\begin{array}{l}=1 \text { if state has a } 0.08 \mathrm{BAC} \text { law, }=0 \\
\text { otherwise }\end{array}$ \\
\hline Beer tax & .208 & .261 & State real beer tax (2000 dollars) \\
\hline Real State Income & 10.4 & 10.3 & $\begin{array}{l}\text { Natural logarithm of state real } \\
\text { income per capita }\end{array}$ \\
\hline Unemployment Rate & 5.74 & 4.45 & State unemployment rate \\
\hline
\end{tabular}

Notes: Means are based on unweighted data from the National Longitudinal Survey of Youth 1997. 
Panel A: Marijuana Use in Past 30 Days

MML

Observations
.001

(.016)

40,986
.007

(.018)

40,986
40,986

$-.004$

Panel B: Frequent Marijuana Use in Past 30 Days

MML

.011

(.010)

Observations

Individual FEs

Year FEs

Covariates

State linear trends
40,986

Yes

Yes

No

No
.013

$(.011)$

40,986

Yes

Yes

Yes

No
.008

$(.014)$

40,986

Yes

Yes

Yes

Yes

* Statistically significant at $10 \%$ level; ** at 5\% level; *** at $1 \%$ level.

Notes: Each cell represents a separate OLS estimate based on data from the National Longitudinal Survey of Youth 1997; the covariates are listed in Table 7. Standard errors, corrected for clustering at the state level, are in parentheses. 
Table 9. Descriptive Statistics: Treatment Episode Data Analysis

\begin{tabular}{|c|c|c|c|}
\hline & MML = 1 & $\mathrm{MML}=0$ & Description \\
\hline \multicolumn{4}{|l|}{ Dependent Variables } \\
\hline $\begin{array}{l}\text { Marijuana admission } \\
\text { rate, ages } 15-17\end{array}$ & 1,326 & 779 & $\begin{array}{l}\text { Marijuana admission rate for } \\
15 \text { - through } 17 \text {-year-olds per } \\
100,000\end{array}$ \\
\hline $\begin{array}{l}\text { Marijuana admission } \\
\text { rate, ages } 18-20\end{array}$ & 817 & 657 & $\begin{array}{l}\text { Marijuana admission rate for } \\
18 \text { - through } 20 \text {-year-olds per } \\
100,000\end{array}$ \\
\hline \multicolumn{4}{|l|}{ Independent Variables } \\
\hline Male rate & .500 & .504 & $\begin{array}{l}=1 \text { if admissions rate is for } \\
\text { males, }=0 \text { otherwise }\end{array}$ \\
\hline Decriminalization Law & .587 & .181 & $\begin{array}{l}=1 \text { if state has decriminalized } \\
\text { marijuana, = } 0 \text { otherwise }\end{array}$ \\
\hline BAC 0.08 Law & .903 & .513 & $\begin{array}{l}=1 \text { if state has a } 0.08 \mathrm{BAC} \\
\text { law, }=0 \text { otherwise }\end{array}$ \\
\hline Beer tax & .258 & .256 & $\begin{array}{l}\text { State real beer tax ( } 2000 \\
\text { dollars) }\end{array}$ \\
\hline Real State Income & 10.3 & 10.2 & $\begin{array}{l}\text { Natural logarithm of state real } \\
\text { income per capita }\end{array}$ \\
\hline Unemployment Rate & 5.72 & 5.12 & State unemployment rate \\
\hline
\end{tabular}

Notes: Means are based on unweighted data from the Treatment Episode Data Set (1992-2009). 
Table 10. Medical Marijuana Laws and Treatment Episodes

(1)

Marijuana admission

rate, ages $15-17$
(2)

Marijuana admission rate, ages $15-17$
$(.113)$

$-.034$

$(.120)$

1737 .852

(3)

Marijuana admission rate, ages $15-17$ $-.067$

$(.115)$

\begin{tabular}{llll}
$\mathrm{N}$ & 1737 & 1737 & 1737 \\
$\mathrm{R}^{2}$ & .608 & .852 & .909 \\
\hline
\end{tabular}

(1)

Marijuana admission rate, ages $18-20$ $-.045$ (.068)
(2) Marijuana admission rate, ages $18-20$ $-.026$ (.068)
(3) Marijuana admission rate, ages $18-20$ $-.061$ $(.051)$

\begin{tabular}{lccc}
$\mathrm{N}$ & 1756 & 1756 & 1756 \\
$\mathrm{R}^{2}$ & .493 & .873 & .899 \\
\hline State FE & Yes & Yes & Yes \\
Year FE & Yes & Yes & Yes \\
Covariates & No & Yes & Yes \\
State linear trends & No & No & Yes \\
\hline
\end{tabular}

* Statistically significant at $10 \%$ level; ${ }^{* *}$ at $5 \%$ level; ${ }^{* * *}$ at $1 \%$ level.

Notes: Each cell represents a separate OLS estimate based on data from the Treatment Episode Data Set (19922009). The dependent variable is equal to the natural log of the marijuana admissions rate per 100,000 population; the covariates are listed in Table 9. Regressions are weighted using the relevant state age- and gender-specific populations. Standard errors, corrected for clustering at the state level, are in parentheses. 
Appendix Table 1. Medical Marijuana Laws, 1993-2011

Effective date

\begin{tabular}{ll}
\hline Alaska & March 4, 1999 \\
Arizona & April 14, 2011 \\
California & November 6, 1996 \\
Colorado & June 1, 2001 \\
Delaware & May 13, 2011 \\
District of Columbia & July 27, 2010 \\
Hawaii & December 28, 2000 \\
Maine & December 22, 1999 \\
Michigan & December 4, 2008 \\
Montana & November 2, 2004 \\
Nevada & October 1, 2001 \\
New Jersey & October 1, 2010 \\
New Mexico & July 1, 2007 \\
Oregon & December 3, 1998 \\
Rhode Island & January 3, 2006 \\
Vermont & July 1, 2004 \\
Washington & November 3, 1998 \\
\hline
\end{tabular}

Note: In Connecticut, the legalization of medical marijuana is scheduled to take place on October 1, 2012. 
Appendix Table 2. Number of Observations by State-Year: National YRBS

\begin{tabular}{|c|c|c|c|c|c|c|c|c|c|c|c|}
\hline & 1993 & 1995 & 1997 & 1999 & 2001 & 2003 & 2005 & 2007 & 2009 & 2011 & Total \\
\hline$\overline{\mathrm{AL}}$ & 782 & 97 & 781 & 55 & 306 & 630 & $\ldots$ & 475 & 1,027 & 308 & 4,461 \\
\hline $\mathrm{AZ}^{*}$ & 429 & $\ldots$ & 1,076 & 130 & 399 & 341 & 279 & 588 & 353 & 1,087 & 4,462 \\
\hline AR & 393 & 282 & 358 & $\ldots$ & $\ldots$ & 261 & $\ldots$ & 411 & 297 & $\ldots$ & 2,002 \\
\hline $\mathrm{CA}^{*}$ & 2,082 & 1,161 & 1,929 & 2,423 & 2,139 & 1,672 & 1,527 & 2,072 & 2,741 & 1,796 & 19,542 \\
\hline CO* & 256 & 99 & 267 & $\ldots$ & 635 & $\ldots$ & $\ldots$ & $\ldots$ & 189 & 234 & 1,680 \\
\hline CT & $\ldots$ & $\ldots$ & 217 & $\ldots$ & $\ldots$ & $\ldots$ & 230 & $\ldots$ & $\ldots$ & $\ldots$ & 447 \\
\hline $\mathrm{DE}^{*}$ & $\ldots$ & 212 & $\ldots$ & $\ldots$ & $\ldots$ & 360 & $\ldots$ & $\ldots$ & $\ldots$ & 221 & 793 \\
\hline DC* & $\ldots$ & 499 & $\ldots$ & $\ldots$ & $\ldots$ & $\ldots$ & $\ldots$ & $\ldots$ & $\ldots$ & 295 & 794 \\
\hline FL & 513 & 532 & 664 & 845 & 1,042 & 1,393 & 532 & 732 & 222 & 1,361 & 7,836 \\
\hline GA & 893 & 435 & 339 & 800 & 476 & 408 & 1,796 & 344 & 1,296 & 120 & 6,907 \\
\hline $\mathrm{HI}^{*}$ & $\ldots$ & $\ldots$ & $\ldots$ & 301 & $\ldots$ & $\ldots$ & $\ldots$ & $\ldots$ & 229 & $\ldots$ & 530 \\
\hline ID & $\ldots$ & $\ldots$ & $\ldots$ & $\ldots$ & 155 & $\ldots$ & 238 & $\ldots$ & $\ldots$ & 258 & 651 \\
\hline IL & 702 & 237 & $\ldots$ & 224 & 431 & 312 & 471 & 576 & 1,450 & 972 & 5,375 \\
\hline IN & $\ldots$ & $\ldots$ & $\ldots$ & $\ldots$ & 176 & 407 & 169 & 395 & $\ldots$ & 266 & 1,413 \\
\hline IA & $\ldots$ & 241 & 774 & $\ldots$ & $\ldots$ & $\ldots$ & 236 & 245 & $\ldots$ & $\ldots$ & 1,496 \\
\hline $\mathrm{KS}$ & 170 & $\ldots$ & 201 & $\ldots$ & $\ldots$ & 307 & 275 & $\ldots$ & 197 & 295 & 1,445 \\
\hline $\mathrm{KY}$ & $\ldots$ & $\ldots$ & $\ldots$ & $\ldots$ & $\ldots$ & $\ldots$ & 527 & 357 & $\ldots$ & 211 & 1,095 \\
\hline LA & $\ldots$ & 278 & 568 & 606 & $\ldots$ & 677 & 155 & $\ldots$ & 411 & $\ldots$ & 2,695 \\
\hline ME* & 247 & 150 & 236 & 196 & 199 & 197 & $\ldots$ & $\ldots$ & $\ldots$ & $\ldots$ & 1,225 \\
\hline MD & 144 & $\ldots$ & 801 & $\ldots$ & $\ldots$ & 260 & $\ldots$ & $\ldots$ & $\ldots$ & $\ldots$ & 1,205 \\
\hline MA & 357 & 269 & 1,606 & $\ldots$ & 249 & 211 & 255 & 708 & $\ldots$ & 282 & 3,937 \\
\hline $\mathrm{MI}^{*}$ & 144 & 1,076 & 490 & 509 & 329 & 392 & 283 & 295 & 313 & 617 & 4,448 \\
\hline $\mathrm{MN}$ & 319 & $\ldots$ & $\ldots$ & $\ldots$ & $\ldots$ & $\ldots$ & 95 & $\ldots$ & 185 & $\ldots$ & 599 \\
\hline MS & 352 & 478 & 326 & 624 & 335 & $\ldots$ & $\ldots$ & 348 & $\ldots$ & 93 & 2,556 \\
\hline MO & 181 & 540 & $\ldots$ & 550 & 458 & 260 & 102 & 343 & 84 & 341 & 2,859 \\
\hline $\mathrm{MT}^{*}$ & $\ldots$ & $\ldots$ & $\ldots$ & $\ldots$ & 197 & $\ldots$ & $\ldots$ & $\ldots$ & $\ldots$ & $\ldots$ & 197 \\
\hline $\mathrm{NE}$ & 396 & $\ldots$ & $\ldots$ & $\ldots$ & $\ldots$ & $\ldots$ & $\ldots$ & $\ldots$ & $\ldots$ & $\ldots$ & 396 \\
\hline $\mathrm{NV}^{*}$ & $\ldots$ & $\ldots$ & $\ldots$ & $\ldots$ & 232 & $\ldots$ & $\ldots$ & $\ldots$ & 378 & 198 & 808 \\
\hline NJ* & $\ldots$ & $\ldots$ & 720 & 232 & 213 & 297 & 309 & 669 & 364 & 111 & 2,915 \\
\hline $\mathrm{NM}^{*}$ & 657 & $\ldots$ & 276 & $\ldots$ & 152 & 100 & $\ldots$ & 218 & 596 & $\ldots$ & 1,999 \\
\hline NY & 1,217 & 510 & 355 & 700 & 298 & 893 & 450 & 894 & 1,159 & 622 & 7,098 \\
\hline
\end{tabular}


Appendix Table 2. Number of Observations by State-Year: National YRBS (continued)

\begin{tabular}{|c|c|c|c|c|c|c|c|c|c|c|c|}
\hline & 1993 & 1995 & 1997 & 1999 & 2001 & 2003 & 2005 & 2007 & 2009 & 2011 & Total \\
\hline $\mathrm{NC}$ & 296 & 114 & 327 & 506 & 659 & 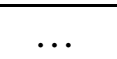 & 628 & 558 & $\ldots$ & 686 & 3,774 \\
\hline $\mathrm{OH}$ & 524 & 546 & 538 & 551 & 221 & 290 & 270 & $\ldots$ & $\ldots$ & $\ldots$ & 2,940 \\
\hline OK & $\ldots$ & $\ldots$ & 223 & $\ldots$ & 392 & $\ldots$ & 232 & 277 & $\ldots$ & $\ldots$ & 1,124 \\
\hline $\mathrm{OR}^{*}$ & 188 & $\ldots$ & $\ldots$ & $\ldots$ & 183 & $\ldots$ & 268 & $\ldots$ & 243 & $\ldots$ & 882 \\
\hline PA & 356 & 658 & 271 & 477 & $\ldots$ & 316 & 407 & 210 & 1,039 & 408 & 4,142 \\
\hline $\mathrm{RI}^{*}$ & $\ldots$ & $\ldots$ & $\ldots$ & 74 & $\ldots$ & $\ldots$ & $\ldots$ & $\ldots$ & $\ldots$ & $\ldots$ & 74 \\
\hline SC & 390 & $\ldots$ & 330 & 776 & $\ldots$ & 874 & 283 & $\ldots$ & $\ldots$ & $\ldots$ & 2,653 \\
\hline SD & $\ldots$ & $\ldots$ & $\ldots$ & $\ldots$ & $\ldots$ & 295 & $\ldots$ & $\ldots$ & $\ldots$ & $\ldots$ & 295 \\
\hline $\mathrm{TN}$ & 507 & 346 & 564 & 263 & 588 & $\ldots$ & 391 & 162 & $\ldots$ & 286 & 3,107 \\
\hline $\mathrm{TX}$ & 2,715 & 1,642 & 935 & 2,668 & 2,006 & 2,574 & 1,705 & 1,438 & 1,312 & 1,721 & 18,716 \\
\hline UT & $\ldots$ & $\ldots$ & $\ldots$ & $\ldots$ & $\ldots$ & 178 & 268 & 193 & $\ldots$ & $\ldots$ & 639 \\
\hline VT* & $\ldots$ & $\ldots$ & $\ldots$ & $\ldots$ & $\ldots$ & 57 & $\ldots$ & $\ldots$ & $\ldots$ & $\ldots$ & 57 \\
\hline VA & $\ldots$ & 64 & $\ldots$ & 718 & $\ldots$ & 240 & 345 & 424 & 96 & 201 & 2,088 \\
\hline WA* & 373 & 82 & 103 & $\ldots$ & 52 & $\ldots$ & 100 & $\ldots$ & 245 & 165 & 1,120 \\
\hline WV & 301 & $\ldots$ & $\ldots$ & $\ldots$ & 260 & $\ldots$ & 228 & 243 & 457 & 251 & 1,740 \\
\hline WI & & & 289 & 521 & 234 & 175 & 239 & 178 & 675 & 645 & 2,956 \\
\hline
\end{tabular}

Notes: States that legalized medical marijuana are denoted with a star superscript and post-legalization observations are italicized. 
Appendix Table 3. Number of Observations by State-Year: State YRBS

\begin{tabular}{|c|c|c|c|c|c|c|c|c|c|c|c|}
\hline & 1993 & 1995 & 1997 & 1999 & 2001 & 2003 & 2005 & 2007 & 2009 & 2011 & Total \\
\hline $\mathrm{AL}$ & 4,269 & 3,773 & 3,544 & 2,007 & 1,508 & 1,038 & 975 & & 1,418 & 1,328 & 19,860 \\
\hline $\mathrm{AK}^{*}$ & $\ldots$ & 1,595 & $\ldots$ & $\ldots$ & $\ldots$ & 1,414 & $\ldots$ & 1,256 & 1,302 & 1,278 & 6,845 \\
\hline $\mathrm{AZ}^{*}$ & $\ldots$ & $\ldots$ & $\ldots$ & $\ldots$ & $\ldots$ & 1,939 & 1,872 & 1,668 & 1,484 & 1,948 & 8,911 \\
\hline $\mathrm{AR}$ & $\ldots$ & 2,223 & 1,950 & 1,426 & 1,661 & $\ldots$ & 1,438 & 1,535 & 1,580 & 1,302 & 13,115 \\
\hline $\mathrm{CO}^{*}$ & $\ldots$ & $\ldots$ & $\ldots$ & $\ldots$ & $\ldots$ & $\ldots$ & 1,459 & $\ldots$ & 1,451 & 1,437 & 4,347 \\
\hline $\mathrm{CT}$ & $\ldots$ & $\ldots$ & 1,709 & $\ldots$ & $\ldots$ & $\ldots$ & 2,108 & 1,974 & 2,298 & 1,968 & 10,057 \\
\hline $\mathrm{DE}^{*}$ & $\ldots$ & $\ldots$ & $\ldots$ & 2,313 & 2,842 & 2,955 & 2,604 & 2,387 & 2,267 & 2,165 & 17,533 \\
\hline ID & 3,907 & $\ldots$ & $\ldots$ & $\ldots$ & 1,680 & 1,694 & 1,414 & 1,378 & 2,114 & 1,663 & 13,850 \\
\hline IL & 3,953 & 3,020 & $\ldots$ & $\ldots$ & $\ldots$ & $\ldots$ & $\ldots$ & 2,326 & 2,887 & 3,403 & 15,589 \\
\hline IA & $\ldots$ & $\ldots$ & 1,498 & $\ldots$ & $\ldots$ & $\ldots$ & 1,339 & 1,425 & $\ldots$ & 1,519 & 5,781 \\
\hline $\mathrm{KS}$ & $\ldots$ & $\ldots$ & $\ldots$ & $\ldots$ & $\ldots$ & $\ldots$ & 1,618 & 1,682 & 1,991 & 1,823 & 7,114 \\
\hline KY & $\ldots$ & $\ldots$ & 1,561 & $\ldots$ & $\ldots$ & 1,528 & 3,178 & 3,391 & 1,692 & 1,650 & 13,000 \\
\hline $\mathrm{ME}^{*}$ & $\ldots$ & 1,375 & 1,795 & 1,305 & $\ldots$ & 1,616 & 1,304 & 1,277 & 8,419 & 8,982 & 26,073 \\
\hline MD & $\ldots$ & $\ldots$ & $\ldots$ & $\ldots$ & $\ldots$ & $\ldots$ & 1,373 & 1,467 & 1,562 & 2,529 & 6,931 \\
\hline $\mathrm{MI}^{*}$ & $\ldots$ & $\ldots$ & 4,277 & 2,600 & 3,472 & 3,332 & 3,144 & 3,390 & 3,271 & 4,052 & 27,538 \\
\hline MS & 1,431 & 1,251 & 1,462 & 1,579 & 1,777 & 1,458 & & 1,537 & 1,749 & 1,729 & 13,973 \\
\hline MO & $\ldots$ & 4,787 & 1,451 & 1,601 & 1,625 & 1,530 & 1,851 & 1,512 & 1,595 & $\ldots$ & 15,952 \\
\hline $\mathrm{MT}^{*}$ & 4,936 & 2,476 & 2,502 & 2,856 & 2,572 & 2,617 & 2,947 & 3,849 & 1,766 & 4,002 & 30,523 \\
\hline $\mathrm{NE}$ & 3,154 & $\ldots$ & $\ldots$ & $\ldots$ & $\ldots$ & 2,862 & 3,651 & $\ldots$ & $\ldots$ & 2,644 & 12,311 \\
\hline $\mathrm{NV}^{*}$ & 2,001 & 1,507 & 1,441 & 1,659 & 1,405 & 1,917 & 1,488 & 1,737 & 2,007 & $\ldots$ & 15,162 \\
\hline $\mathrm{NH}$ & 2,651 & 2,128 & $\ldots$ & $\ldots$ & $\ldots$ & 1,294 & 1,249 & 1,595 & 1,459 & 1,378 & 11,754 \\
\hline NJ* & $\ldots$ & $\ldots$ & $\ldots$ & $\ldots$ & 2,026 & $\ldots$ & 1,470 & $\ldots$ & 1,716 & 1,619 & 6,831 \\
\hline $\mathrm{NM}^{*}$ & $\ldots$ & $\ldots$ & $\ldots$ & $\ldots$ & $\ldots$ & $\ldots$ & 5,020 & 2,539 & 4,835 & 5,596 & 18,290 \\
\hline NY & $\ldots$ & $\ldots$ & 3,673 & 3,303 & $\ldots$ & 9,021 & 9,194 & 12,780 & 13,959 & 12,544 & 64,474 \\
\hline NC & 2,686 & 1,921 & $\ldots$ & $\ldots$ & 2,477 & 2,479 & 3,762 & 3,363 & 5,485 & 2,174 & 24,347 \\
\hline ND & $\ldots$ & $\ldots$ & $\ldots$ & 1,800 & 1,564 & 1,636 & 1,700 & 1,725 & 1,782 & 1,873 & 12,080 \\
\hline $\mathrm{RI}^{*}$ & $\ldots$ & $\ldots$ & 1,476 & $\ldots$ & 1,351 & 1,759 & 2,302 & 2,102 & 3,093 & 3,813 & 15,896 \\
\hline SC & 4,636 & 5,302 & 5,347 & 4,449 & $\ldots$ & 1,238 & 1,202 & 1,202 & 1,055 & 1,382 & 24,612 \\
\hline SD & 1,326 & 1,170 & 1,577 & 1,639 & 1,564 & 1,762 & 1,544 & 1,561 & 2,115 & 1,507 & 15,765 \\
\hline $\mathrm{TN}$ & 3,226 & $\ldots$ & $\ldots$ & $\ldots$ & $\ldots$ & 1,899 & 1,519 & 2,020 & 2,176 & 2,584 & 13,464 \\
\hline TX & $\ldots$ & $\ldots$ & $\ldots$ & $\ldots$ & 6,864 & $\ldots$ & 4,032 & 3,123 & 3,459 & 4,017 & 21,495 \\
\hline
\end{tabular}


Appendix Table 3. Number of Observations by State-Year: State YRBS (continued)

\begin{tabular}{lccccccccccc}
\hline & 1993 & 1995 & 1997 & 1999 & 2001 & 2003 & 2005 & 2007 & 2009 & 2011 & Total \\
\hline UT & 4,376 & 3,123 & 1,340 & 1,467 & 1,029 & 1,350 & 1,401 & 1,885 & 1,538 & 1,651 & 19,160 \\
VT* & $\ldots$ & 5,860 & 6,783 & $\ldots$ & 6,942 & 5,901 & 6,941 & 5,825 & 8,347 & $\ldots$ & 46,599 \\
WV & 2,778 & 2,045 & 1,796 & 1,365 & $\ldots$ & 1,701 & 1,298 & 1,358 & 1,578 & 2,121 & 16,040 \\
WI & 3,199 & $\ldots$ & 1,294 & 1,304 & 2,070 & 2,078 & 2,250 & 2,050 & 2,391 & 2,941 & 19,577 \\
\hline
\end{tabular}

Notes: States that legalized medical marijuana are denoted with a star superscript and post-legalization observations are italicized. 


\section{$\underline{\text { National YRBS }}$}

Panel A: Marijuana Use in Past 30 Days

$\begin{array}{lccc}\text { MML } & -.019 & -.016 & -.004 \\ & (.015) & (.013) & (.018) \\ \text { Observations } & 140,393 & 140,393 & 140,393\end{array}$

Panel B: Frequent Marijuana Use in Past 30 Days

MML

$-.006$

$-.005$

.013

$(.015)$

(.013)

(.015)

Observations

140,393

140,393

140,393

State FEs

Yes

Yes

Yes

Year FEs

Yes

Yes

Yes

Covariates

No

Yes

Yes

State-specific trends

No

No

Yes

* Statistically significant at $10 \%$ level; ** at 5\% level; *** at $1 \%$ level.

Notes: Each cell represents a separate OLS estimate based on data from the YRBS (1993-2011); the covariates are listed in Table 1. Standard errors, corrected for clustering at the state level, are in parentheses. 
$\underline{\text { National YRBS }}$

Panel A: Marijuana Use in Past 30 Days

MML

\begin{tabular}{lccc} 
Male & Female & Age $<17$ & Age $\geq 17$ \\
\hline-.018 & .010 & -.030 & .040 \\
$(.020)$ & $(.021)$ & $(.018)$ & $(.030)$
\end{tabular}

Observations

68,675

71,718

80,494

59,899

Panel B: Frequent Marijuana Use in Past 30 Days

MML

$\begin{array}{cccc}\text { Male } & \text { Female } & \text { Age }<17 & \text { Age } \geq 17 \\ .025 & .000 & .009 & .023 \\ (.017) & (.017) & (.019) & (.014)\end{array}$

Observations

68,675

71,718

80,494

59,899

State FEs

Yes

Yes

Yes

Yes

Yes

Yes

Year FEs

Yes

Yes

Yes

Yes

Covariates

Yes

Yes

Yes

Yes

State-specific trends

Yes

Yes

* Statistically significant at $10 \%$ level; ** at $5 \%$ level; *** at $1 \%$ level.

Notes: Each cell represents a separate OLS estimate based on data from the YRBS (1993-2011); the covariates are listed in Table 1. Standard errors, corrected for clustering at the state level, are in parentheses. 


\section{Appendix Table 6. Weighted NLSY97 Analysis}

Panel A: Marijuana Use in Past 30 Days

MML

$-.003$

.003

$-.010$

$(.014)$

$(.022)$

Observations

40,986

40,986

40,986

Panel B: Frequent Marijuana Use in Past 30 Days

MML

$$
.011
$$

$(.011)$

40,986

Yes

Yes

No

No
.015

(.011)

40,986

Yes

Yes

Yes

No
.009

(.016)

40,986

Yes

Yes

Yes

Yes

* Statistically significant at $10 \%$ level; ** at $5 \%$ level; *** at $1 \%$ level.

Notes: Each cell represents a separate OLS estimate based on data from the National Longitudinal Survey of Youth 1997; the covariates are listed in Table 7. Standard errors, corrected for clustering at the state level, are in parentheses. 